\title{
Use of folding modulators to improve heterologous protein production in Escherichia coli Olga Kolaj ${ }^{1}$, Stefania Spada1 ${ }^{1}$, Sylvain Robin ${ }^{2,3}$ and J Gerard Wall*1,2,3
}

Address: ${ }^{1}$ Department of Chemical and Environmental Sciences and Materials and Surface Science Institute, University of Limerick, National Technology Park, Limerick, Ireland, 2Department of Microbiology, School of Natural Sciences, National University of Ireland, Galway, Galway, Ireland and ${ }^{3}$ National Centre for Biomedical Engineering Science, National University of Ireland, Galway, Galway, Ireland

Email: Olga Kolaj - olga.kolaj@ul.ie; Stefania Spada - sspada@eircom.net; Sylvain Robin - sylvain.robin@nuigalway.ie; J

Gerard Wall* - gerard.wall@ nuigalway.ie

* Corresponding author

Published: 27 January 2009

Microbial Cell Factories 2009, 8:9

doi:10.1186/1475-2859-8-9

Received: 8 December 2008

Accepted: 27 January 2009

This article is available from: http://www.microbialcellfactories.com/content/8/l/9

(c) 2009 Kolaj et al; licensee BioMed Central Ltd.

This is an Open Access article distributed under the terms of the Creative Commons Attribution License (http://creativecommons.org/licenses/by/2.0), which permits unrestricted use, distribution, and reproduction in any medium, provided the original work is properly cited.

\begin{abstract}
Despite the fundamental importance of $E$. coli in the manufacture of a wide range of biotechnological and biomedical products, extensive process and/or target optimisation is routinely required in order to achieve functional yields in excess of low $\mathrm{mg} / \mathrm{l}$ levels. Molecular chaperones and folding catalysts appear to present a panacea for problems of heterologous protein folding in the organism, due largely to their broad substrate range compared with, e.g., protein-specific mutagenesis approaches. Painstaking investigation of chaperone overproduction has, however, met with mixed - and largely unpredictable - results to date. The past 5 years have nevertheless seen an explosion in interest in exploiting the native folding modulators of $E$. coli, and particularly cocktails thereof, driven largely by the availability of plasmid systems that facilitate simultaneous, non-rational screening of multiple chaperones during recombinant protein expression. As interest in using $E$. coli to produce recombinant membrane proteins and even glycoproteins grows, approaches to reduce aggregation, delay host cell lysis and optimise expression of difficult-toexpress recombinant proteins will become even more critical over the coming years. In this review, we critically evaluate the performance of molecular chaperones and folding catalysts native to $E$. coli in improving functional production of heterologous proteins in the bacterium and we discuss how they might best be exploited to provide increased amounts of correctly-folded, active protein for biochemical and biophysical studies.
\end{abstract}

\section{Background}

E. coli is preferred for heterologous protein production because of its fast growth, simple fermentation, uncomplicated nutritional and sterility requirements, and extensive characterisation [1]. Despite its widespread use [2], however, many heterologous proteins are produced as insoluble aggregates in cytoplasmic or periplasmic inclusion bodies, while the membrane leakiness and cell lysis associated with making heterologous proteins in E. coli, leading to significantly reduced yields, have also been well documented $[3,4]$.

The discovery of molecular chaperones and folding catalysts appeared to present a panacea for protein aggregation and cell lysis problems in E. coli [5-7]. Molecular chaperones prevent aggregation by binding exposed hydrophobic moieties in unfolded, partially folded or misfolded polypeptides and traffic molecules to their sub- 
cellular destination, while folding catalysts catalyse potentially rate-limiting steps in the folding process, such as peptidyl bond isomerisation or disulfide bond formation. Painstaking investigation of these molecules has met with disparate results to date as simple overexpression of a single modulator in the absence of its accessory molecules frequently sees no positive effect - and may simply increase the production load to the further detriment of the recombinant target. In the absence of an ability to predict the relevant bottleneck in E. coli, therefore, an increasingly common approach by researchers is the use of chaperone "cocktails", which is facilitated by the recent availability of a number of plasmid systems that can be used to co-produce up to 6-7 folding modulators with a heterologous protein $[8,9]$.
A universal system of producing active, recombinant proteins in E. coli remains a core objective of the biotechnology industry. In this paper, we review progress in exploiting folding modulators from $E$. coli to improve the functional production of heterologous proteins.

\section{Folding in the cytoplasm}

The major groups of molecular chaperones involved in protein folding in the E. coli cytoplasm are the peptidylprolyl cis-trans isomerase and molecular chaperone trigger factor (TF) and members of the heat shock protein Hsp70 and Hsp60 families, in addition to ClpB that disaggregates polypeptide aggregates and the small heat shock proteins. The process of polypeptide folding in the E. coli cytoplasm and the chaperones involved are summarised in Figure 1.

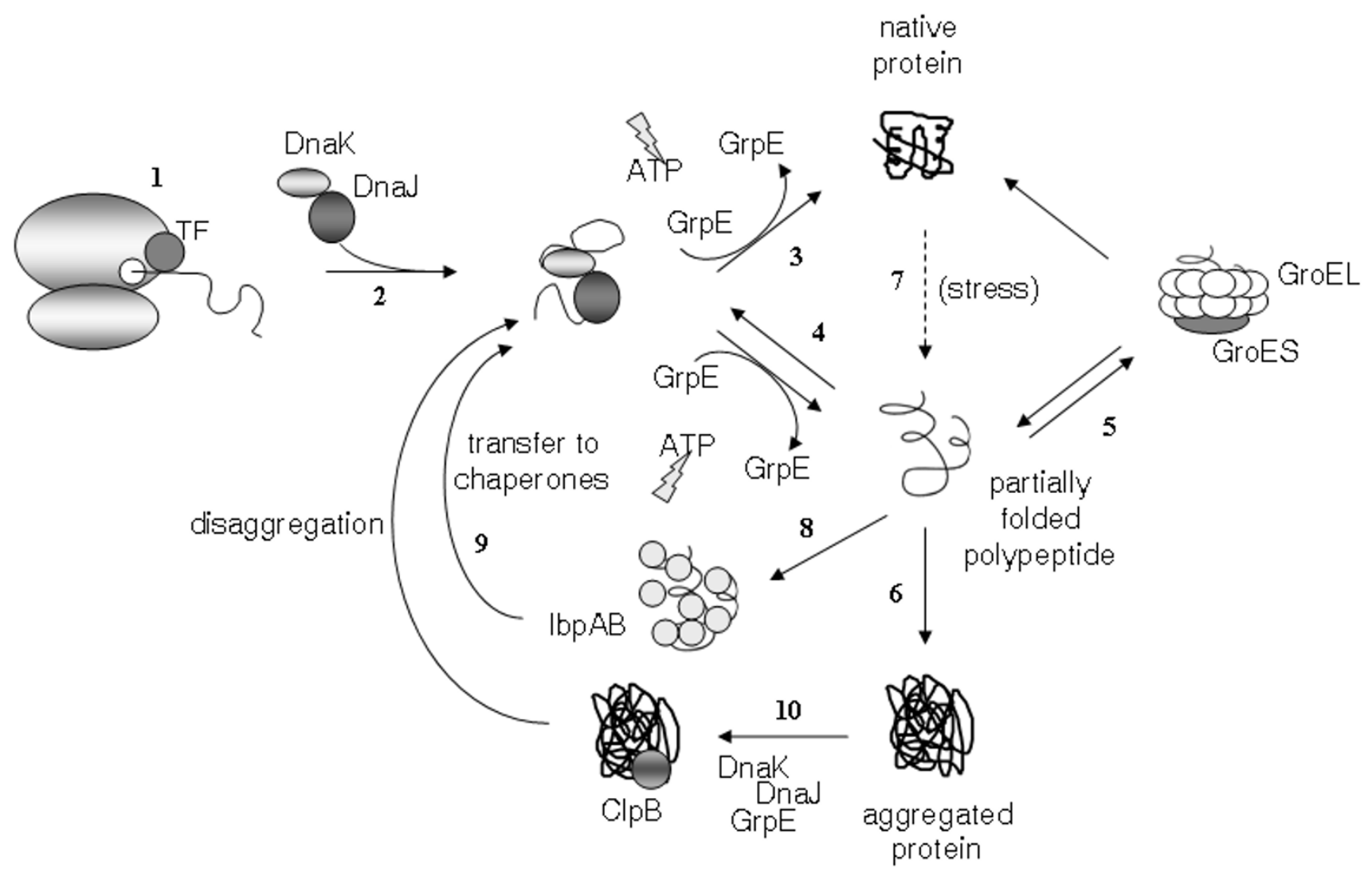

Figure I

The process of protein folding in the E. coli cytoplasm. Nascent polypeptides encounter trigger factor (TF) chaperone upon emerging from the ribosomal exit tunnel (I). They can also be captured by DnaK (2) which cooperates with its cofactor Dnal and nucleotide exchange factor GrpE to promote folding to a native (3) or partially folded conformation. The latter may be re-captured by DnaK (4) and possibly TF to repeat this folding cycle until it reaches its native state, interact with GroELGroES (5) to complete folding to its native conformation, or undergo aggregation (6). Upon heat stress, partial unfolding of thermolabile proteins can occur, resulting in exposure of aggregation-prone hydrophobic regions (7). sHsps such as IbpA and lbpB act to "hold" partially unfolded proteins for transfer to Hsp70 and Hsp60 chaperones DnaK and GroEL (8,9), while disaggregation of unfolded proteins is carried out by ClpB in cooperation with the Hsp70 family ( 10$)$, followed again by their transfer to the DnaK/Dnaj/GrpE machinery for completion of folding. 


\section{Cytoplasmic PPIases}

Most peptide bonds are synthesised in the trans conformation at the ribosome but both the cis and trans conformations are accessible in peptides. As a result, cis-trans isomerisation of peptidyl-prolyl bonds is a potentially rate-limiting step in the folding process (reviewed in [10]). TF is a cytoplasmic enzyme with PPIase activity and the first chaperone to interact with nascent polypeptides at the ribosome (Figure 1). While it binds the ribosome at a $1: 1$ ratio $[11,12]$, most TF in the cell is proposed to exist in a monomer-dimer equilibrium in the cytosol [13], in which the dimeric state is postulated to have a specific mechanistic role in posttranslational protein folding [14]. The activity of TF in supporting polypeptide folding overlaps at least in part with that of the downstream Hsp70 protein DnaK, as evident from the fact that the loss of either chaperone can be tolerated by E. coli but their combined deletion is lethal under normal growth conditions [15].

\section{Overproduction of trigger factor}

As TF displays both chaperone and PPIase activity in vivo and in vitro $[16,17]$, it has been the subject of considerable interest in co-production experiments - despite the fact that the majority of newly synthesised polypeptides do not require it for de novo folding [18]. Nevertheless, TF coproduction led to a 4-fold increase in expression of an anti-digoxin Fab antibody fragment in the E. coli cytoplasm [19] and a higher yield of soluble human ORP150 and lysozyme [17], with further improvements in expression and solubility achieved in the latter case by co-overproducing the Hsp60 GroESL. Similarly, a 3.8-fold increase in the solubility of human translation initiation factor eIF2 $\alpha$ was noted upon TF and GroESL co-overproduction [20], though the addition of GroESL to successful TF co-production experiments can also be un- [17] or counter-productive [21].

TF co-production can also be synergistic with that of Hsp70 family members DnaK-DnaJ-GrpE, as observed in a temperature-dependent effect on guinea pig liver transglutaminase production [22] and vasostatin [23], which may be linked to TF's reported in vivo role in enhancing cell viability at low temperatures [24]. In an attempt to determine the mode of action of TF, mutants with very low PPIase activities were found to enhance soluble production of an adenylate kinase to the same extent as wildtype TF [25], indicating that the effect of TF on at least some recombinant proteins may be due to its chaperoning rather than isomerisation activity. The observation that human FKBP12, which has PPIase but no chaperonelike activity, did not improve expression of a thiosulfate sulfurtransferase enzyme that benefitted from co-production of an archaeal FKBP [26] provides additional evidence that many of the positive effects of PPIases in foreign protein production may relate to their chaperonelike rather than their isomerisation activity.

\section{Hsp70 family}

The heat shock protein 70 (Hsp70) family of proteins are ubiquitous, highly conserved molecules whose predominant unifying feature is the ability to bind short, linear hydrophobic regions of polypeptides $[27,28]$. In addition to their role under heat stress, they assist in folding of newly translated polypeptides and subcellular trafficking of polypeptides under normal physiological conditions. Members of the family contain an ATPase domain and a more variable, peptide-binding domain and polypeptide binding and release is carried out in a cycle between an ATP-bound DnaK molecule with low substrate affinity and a high substrate affinity, ADP-bound state [29].

The activity of DnaK is dependent on the proteins DnaJ and GrpE in E. coli. DnaJ contains a highly conserved Nterminal region that interacts with DnaK, followed by a glycine/phenylalanine-rich region, a zinc finger domain that mediates polypeptide binding, and a variable C-terminal domain [29-31]. Following transient association between DnaK and DnaJ with concomitant ATP hydrolysis, GrpE catalyses the release of ADP from the DnaKADP-peptide complex. In this state, ATP is rapidly rebound by DnaK, leading to release of the bound polypeptide and of GrpE. This cycle of binding and release may be repeated many times, with the released peptide either recommencing the DnaJ/DnaK cycle, being transferred to the chaperonin GroEL, undergoing further folding steps to reach its native state, or aggregating (Figure 1; [32]).

\section{Overproduction of DnaK-DnaJ-GrpE with cytoplasmic proteins}

DnaK-DnaJ-GrpE chaperones are most commonly overproduced with cytoplasmic recombinant proteins, due to their own location in the cytoplasm. This approach has enabled the successful production of a number of proteins otherwise produced mainly or exclusively as inclusion bodies, such as a single-chain antibody fragment (scFv; [33]), human tyrosine kinases Csk, Fyn and Lck [34], an Acinetobacter cyclohexanone monooxygenase [35], and a cedar pollen allergen [36]. DnaK-DnaJ without GrpE have also been reported to increase production (red sea bream transglutaminase; [37]), suppress aggregation (human SPARC - secreted protein acidic and rich in cysteine; [38]), improve solubility (Agrobacterium D-hydantoinase; [39]), and increase the activity ( $\beta$-galactosidase fusion protein; [40]) of numerous recombinant proteins. This improved production is generally due to increased solubility of recombinant targets rather than an increase in cellular production levels, though Nishihara and co-workers [17] reported a decrease in total murine endostatin concomitant with increased levels of soluble protein upon 
DnaK-DnaJ-GrpE overproduction. It should, however, be noted that increased solubility is not always accompanied by an increase in protein quality and so determination of solubility may not always provide an accurate picture of correct folding, as reported in a study of the effects of DnaK levels on a misfolding-prone GFP fusion protein $[41,42]$.

Conversely, DnaK-DnaJ have little effect on the solubility and negative effects on the production and activity of numerous proline-rich targets $[17,39,43]$, which emphasises the benefits of attempting to "match" chaperones to hypothetical bottlenecks in target protein production. Other workers have reported that protein aggregation could be prevented when DnaK-DnaJ-GrpE were coexpressed at 2-3 times wild type levels but that higher chaperone concentrations resulted in a reduced yield of recombinant protein [36]. These results highlight a recurring theme in this field, that chaperone overproduction must be regulated to meet the additional needs of the host cells, rather than serving to add to cellular stress through the high-level production of an irrelevant protein product [44].

The relatively recent availability, both commercial and non-commercial, of sets of $E$. coli chaperone co-production plasmids carrying the groESL, dnaKJ grpE, tig and other chaperone genes, frequently under independently regulated promoters, has led to numerous co-production analyses of Hsp70 proteins in combination with GroESL and trigger factor in particular. The successes reported with a variety of molecules from combining chaperones in this manner $[17,44-47]$ and the ease of carrying out such broad screens means this type of approach will continue to provide an obvious starting point for researchers looking to improve expression of otherwise intransigent proteins.

Overproduction of $\mathrm{Hsp} 70$ family members with periplasmic proteins Hsp70 co-production has also been employed to beneficial effect with heterologous proteins produced in the $E$. coli periplasm, apparently by increasing the solubility of the protein precursor prior to membrane translocation. A 100 -fold increase in the yield of a scFv antibody fragment was observed upon co-producing DnaK-DnaJ-GrpE [48], while export of human granulocyte-colony stimulating factor [49], granulocyte-macrophage colony-stimulating factor and interleukin-13 [50] were greatly improved upon production of DnaK and DnaJ. In all cases, the amount of total cellular protein remained unchanged. A variation on this approach saw export of DnaJ itself to the E. coli periplasm, leading to dramatic (37- to 170-fold) increases in the functional periplasmic yields of a tissue plasminogen activator (tPA) variant and of proinsulin
[51] - though no positive effect was found on a scFv-gene 3 protein fusion in the same study.

\section{Hsp60 family}

The Hsp60 family is the most studied of all the chaperone families and is composed of GroEL and its homologues in prokaryotes, chloroplasts and mitochondria, and the TRiC/TCP-1 family in the eukaryotic cytosol. GroEL is characterised by a fascinating double ring-shaped structure composed of 14 identical subunits, stacked in 2 back to back heptameric rings, which together form a hollow cylinder containing a nucleotide binding site facing into the central channel [52]. GroEL acts by binding unfolded polypeptide at either of the outer ends of its inner cavity through hydrophobic interactions $[53,54]$. This is followed by capping of the cavity by its Hsp10 family cochaperonin GroES, which exists as a single heptameric ring with a hollow dome-shape structure [55] to create a closed environment, with a capacity of approximately 86 $\mathrm{kDa}$ [56], in which substrate folding is favoured. Cycles of peptide binding and release are driven by ATP binding and hydrolysis, promoting a structural stretching of the guest protein until a sufficiently native state is reached such that exposed hydrophobic regions are no longer available to be bound in the GroEL cavity [57]. The demonstration that GroESL mediated folding of an $82-\mathrm{kDa}$ aconitase protein that could not be encapsulated in the central GroEL cavity led more recently to the identification of a less efficient trans mechanism of polypeptide folding by GroEL, in which polypeptides are not encapsulated and the chaperone appears to act more as a holdase, suppressing off-pathway aggregation reactions, than as a foldase ([58]; reviewed in [59]).

\section{Overproduction of GroESL with cytoplasmic, periplasmic proteins} Overproduction of GroESL has proven a highly productive approach to overcoming polypeptide folding problems in E. coli, allowing the soluble production of many recombinant proteins which are otherwise produced exclusively or almost exclusively in inclusion bodies. These include proteins as diverse as human thromboxane synthase [60], nicotinoprotein formaldehyde dismutase from Pseudomonas putida F61 [61], human oxygen-regulated protein ORP150 and human lysozyme [17], a human iron-regulatory protein [62], a putative bacterial dehydratase [63], $\beta$-glucosidases from Cellovibrio gilvus and Agrobacterium tumefaciens [64], murine c-Myb, CAMP response element-binding protein 1, p53 tumour suppresor gene product, Xenopus mos proto-oncogene product [65], bacterial magnesium transporter CorA [66] and triazine hydrolase from Arthrobacter aurescens TC1 [67]. A sample of proteins whose total or functional yield in the E. coli cytoplasm is merely increased upon GroESL overproduction, meanwhile, can be found in Table $1[19,21,36,39,43,58,61,64,68-101]$. 
Table I: Proteins whose total and/or functional yields increase upon co-production of GroESL

\begin{tabular}{|c|c|c|}
\hline Recombinant protein & Effect of co-production of GroESL chaperones & Reference \\
\hline Human procollagenase & GroESL increased production levels by 10 -fold, solubility and half-life & [68] \\
\hline p50 csk Protein-Tyrosine Kinase & Co-production enhanced solubility and activity of the protein by up to $>50 \%$ & [69] \\
\hline Candida albicans PMI metalloenzyme & 2-fold increase in protein solubility & [70] \\
\hline $\begin{array}{l}\alpha \text { and } \beta \text { subunits of human propionyl-CoA } \\
\text { carboxylase (PCC) }\end{array}$ & $\begin{array}{l}\text { Several hundred-fold increase in PCC specific activity; most of the protein } \\
\text { produced in soluble form }\end{array}$ & [7I] \\
\hline Human electron transfer flavoprotein (ETF) & Co-production required for stable expression of ETF $\alpha$ GI I6R mutant & [72] \\
\hline $\begin{array}{l}\beta \text {-glucosidase from Cellovibrio gilvus and } \\
\text { Agrobacterium tumefaciens }\end{array}$ & $\begin{array}{l}\text { Co-production resulted in slower growth rate and reduced yield but increased } \\
\text { solubility of the proteins by } 20-60 \% \text { at } 37^{\circ} \mathrm{C} \text { and up to } 70 \% \text { at } 25^{\circ} \mathrm{C}\end{array}$ & [64] \\
\hline Cryj2 Japanese cedar pollen & $\begin{array}{l}\text { Increased yield and solubility of expressed protein; } 4 \text {-fold stabilisation of the protein } \\
\text { in the presence of a } 10 \text {-fold chaperone excess }\end{array}$ & [36] \\
\hline Human kinase inhibitor-GST fusion & Solubility of otherwise mostly insoluble protein enhanced by $5-6$-fold & [73] \\
\hline Eukaryotic phenylalanine ammonia-lyase & $\begin{array}{l}\text { Dramatically improved yield and activity of the protein after engineering of gene to } \\
\text { remove } E \text {. coli rare codons }\end{array}$ & [74] \\
\hline Bovine adrenodoxin reductase (AdR) & Increased soluble AdR yield to $10 \mathrm{mg} / \mathrm{l}$, compared with $4 \mathrm{mg} / \mathrm{l}$ with $\mathrm{Hsp} 70$ & [75] \\
\hline Cyanobacterium transcription factor & 3-4-fold increase in solubility & [76] \\
\hline $\begin{array}{l}\text { Thermococcus litoralis } 4 \text { - } \alpha \text {-glucanotransferase } \\
\text { (GTase) }\end{array}$ & $\begin{array}{l}\text { Co-production of GroESL with tRNA } \mathrm{AGA}_{\text {and }} \text { tRNA } \mathrm{AGG}_{\mathrm{AG}} \text { led to } 5 \text {-fold increase in } \\
\text { GTase activity in soluble fraction; yield otherwise lower and } 60 \% \text { insoluble }\end{array}$ & [77] \\
\hline Agrobacterium radiobacter carbamoylase & 4-fold increase in activity due to improved solubility & [39] \\
\hline Human cytochrome P450 3A7 (CYP3A7) & Increased expression levels and activity of the otherwise inactive protein & [78] \\
\hline $\begin{array}{l}\text { Decarboxylase component of human } \alpha \text {-keto acid } \\
\text { dehydrogenase complex }\end{array}$ & $\begin{array}{l}\text { Co-production of GroEL or GroES resulted in increase in decarboxylase activity by } \\
500 \text {-fold and } 30 \text {-fold, respectively }\end{array}$ & [79] \\
\hline $\begin{array}{l}\text { Maize plastidic protoporphyrinogen IX oxidase } \\
\text { (PPO) }\end{array}$ & 6-fold increase in soluble PPO yield & {$[80]$} \\
\hline Manganese catalase from Thermus sp. & Increased solubility (up to $50 \%$ ) with GroESL & {$[81]$} \\
\hline p66 and $p 5 I$ subunits of HIV-I RTase & Yield and nucleic acid affinity increased by 4-5- and I.6-fold, respectively & [82] \\
\hline Anti-digoxin Fab antibody fragment & 4-fold increase in solubility of the Fab produced in E. coli Origami strain & [19] \\
\hline Agrobacterium tumefaciens D-carbamoylase (DCB) & $\begin{array}{l}\text { Increase in solubility of DCB up to } 60 \% \text { and activity by } 6.2 \text {-fold at } 28^{\circ} \mathrm{C} \text {; at } 25^{\circ} \mathrm{C} \\
\text { protein solubility increased to } 75 \% \text { and activity by } 4.5 \text {-fold }\end{array}$ & [83] \\
\hline Guinea pig NADPH:quinone oxidoreductase & 3-fold increase in solubility & [84] \\
\hline Aconitase & Solubility and activity increased to $40 \%$ and by 1.5 -fold, respectively & {$[58]$} \\
\hline Rhodococcus erythropolis desulfinase & Solubility of the protein increased up to $40-50 \%$ and activity by 25 -fold & [85] \\
\hline E. coli glutamate racemase (GluR) & Growth of host cells improved; 2.2 -fold increase in yield of active GluR & [86] \\
\hline
\end{tabular}


Table I: Proteins whose total and/or functional yields increase upon co-production of GroESL (Continued)

\begin{tabular}{|c|c|c|}
\hline $\begin{array}{l}\text { Pseudomonas putida F6I nicotinoprotein } \\
\text { formaldehyde dismutase (NDF) }\end{array}$ & $\begin{array}{l}\text { With tac promoter, increased solubility (up to } 80 \% \text { ) and 6-fold higher enzyme } \\
\text { activity; lesser effect when NDF expressed under the lac promoter }\end{array}$ & {$[61]$} \\
\hline Human PP2A methyltransferase & 24-fold increase in solubility & {$[87]$} \\
\hline $\begin{array}{l}\text { Oligo-I,6-glucosidase from Bacillus } \\
\text { thermoglucosidasius }\end{array}$ & $\begin{array}{l}\text { Specific activity increased by } 44 \%, 56 \% \text { and } 56 \% \text { with co-production of GroES, } \\
\text { GroEL and GroESL, respectively }\end{array}$ & [43] \\
\hline $\begin{array}{l}\text { Cyclodextrin gluanotransferase (CGTase) from } \\
\text { Bacillus macerans }\end{array}$ & $\begin{array}{l}\text { Increase in solubility and activity of CGTase by } 12 \% \text { and } 1.5 \text {-fold, respectively, at } \\
37^{\circ} \mathrm{C} \text { and by } 22 \% \text { and } 1.3 \text {-fold, respectively, at } 25^{\circ} \mathrm{C}\end{array}$ & {$[88,89]$} \\
\hline Rhizobium sp. $\alpha-1,6$-fucosyltransferase & At $30^{\circ} \mathrm{C}$, improved folding and an increase in specific activity by 1.76 -fold & [90] \\
\hline Mouse CYP27BI protein & I0-fold increase in the yield of stable and active protein & {$[91]$} \\
\hline $\begin{array}{l}\text { Pyridoxine 4-oxidase (PNO) from Microbacterium } \\
\text { luteolum }\end{array}$ & $\begin{array}{l}\text { No benefit of GroESL at } 37^{\circ} \mathrm{C} \text {; co-production at } 23^{\circ} \mathrm{C} \text { enhanced solubility and } \\
\text { specific activity of PNO by } 1.9 \text {-fold and } 3.9 \text {-fold, respectively }\end{array}$ & [92] \\
\hline $\begin{array}{l}\text { Pyridoxal 4-dehydrogenase from Microbacterium } \\
\text { luteolum }\end{array}$ & $\begin{array}{l}\text { Co-production at } 20^{\circ} \mathrm{C} \text { led to reduced amounts of insoluble protein and increased } \\
\text { specific activity by } 9.1 \text {-fold }\end{array}$ & [93] \\
\hline $\begin{array}{l}\text { Alcaligenes xylosoxydans } \mathrm{N} \text {-acyl-D-amino acid } \\
\text { amidohydrolases }\end{array}$ & $\begin{array}{l}\text { Enzymatic activity of the proteins increased from } 7.8 \text { to } 72.4 \mathrm{U} / \mathrm{mg} \text { and } 7.1 \text { to } 22.7 \\
\mathrm{U} / \mathrm{mg} \text {, respectively, at } 30^{\circ} \mathrm{C}\end{array}$ & {$[21]$} \\
\hline $\begin{array}{l}\text { Human aromatase (P450arom, CYPI9) } \\
\mathrm{NmA264C} \text { and NmA264R mutants }\end{array}$ & $\begin{array}{l}\text { No improvement with } \mathrm{NmA264C} \text {; production of } \mathrm{NmA264R} \text { greatly enhanced } \\
\text { (up to } 400 \mathrm{nmol} / \mathrm{l} \text { ) }\end{array}$ & [94] \\
\hline scFv specific for c-Met & Solubility increased 2-fold in E. coli Origami2(DE3) but not in BL2I(DE3) & [95] \\
\hline Yeast mitochondrial aconitase & Increased solubility at $25^{\circ} \mathrm{C}$ with no change in total yield & [96] \\
\hline human prolyl hydroxylase isoenzyme & 2 -fold increase in solubility when produced at $30^{\circ} \mathrm{C}$ & [97] \\
\hline Pig liver esterase $\gamma$-isoenzyme (PLE) & Enhanced yield of soluble and active PLE in E. coli Origami (DE3) & [98] \\
\hline Soybean seed ferritin complex & Increased solubility of $\mathrm{H}-\mathrm{I}$ subunit from 4 to $39 \%$ and $\mathrm{H}-2$ subunit from 19 to $85 \%$ & [99] \\
\hline Human II $\beta$ hydroxylase & 20- to 40 -fold increase in yield in half the production time & {$[100]$} \\
\hline $\begin{array}{l}\text { Human glucose 6-phosphate dehydrogenase } \\
\text { (G6PD) and mutants }\end{array}$ & $\begin{array}{l}\text { Negligible effect on expression of wild type G6PD but activities of two mutants } \\
\text { were enhanced by } 48-160 \% \text { and } 39-118 \% \text { at } 37^{\circ} \mathrm{C} \text { and } 31^{\circ} \mathrm{C} \text {, respectively }\end{array}$ & {$[101]$} \\
\hline
\end{tabular}

In spite of this impressive track record and the fact that GroEL has been demonstrated to support the folding of a majority of newly translated polypeptides in E. coli [54], GroESL overproduction is still not the much sought-after magic bullet for heterologous protein folding in E. coli. There are numerous reports of GroESL failing to improve protein solubility [102] or rescue recombinant proteins from inclusion bodies [103], even where co-production of Hsp70 family members was successful $[22,37,48]$. Overproduction of GroESL has also been found to lead to reduced enzyme activity [21] and lower viability of host cells during protein production [48]. These failings may reflect a degree of polypeptide specificity on the part of GroESL, as potentially evident in its differing effects on the expression of two human aromatase variants that dif- fer only by a single amino acid residue [94]. Similarly, as discussed above with Hsp70 family members, GroESL overproduction has notably failed to improve the production of proteins with complex disulfide patterns $[38,104,105]$ or in which peptidyl-prolyl cis-trans isomerisation is limiting [106] as the production bottleneck in such cases presumably lies outwith the remit of its chaperoning role.

Co-overproduction of GroESL with DnaK-DnaJ-GrpE and/or TF has led to numerous notable successes over those achievable with GroESL alone, such as with a human translation initiation factor [20], human oxygenregulated protein ORP150 and human lysozyme [17], a D-aminoacylase [21] and, in temperature-dependent 
effects, with a GST-human vasostatin fusion protein [23] and human endostatin [45], all in combination with TF. Combining GroESL with DnaK-DnaJ-GrpE has proven significantly less fruitful, with numerous examples of losses (up to total) of positive effects on solubility or activity upon addition of the second chaperone family to the experimental setup $[21,33,48,107]$. As these multi-chaperone experiments usually have the singular objective of increasing target protein yields, however, they typically lack the detailed mechanistic studies necessary to delineate the effects of individual chaperones. In one attempt to delineate the respective roles of the Hsp60 and Hsp70 families in the cytoplasmic production of a penicillin acylase (PAC) precursor (proPAC), however, $\mathrm{Xu}$ and coworkers reported that the effect of GroESL co-production was to prevent intracellular proteolysis while DnaK-DnaJGrpE led to improved solubilisation of proPAC and improved PAC maturation [108].

While some success has resulted from co-producing chaperones such as DnaK with periplasm-destined recombinant proteins, comparably little success has accrued with GroES and GroEL. Thus it appears that, while GroESL overproduction represents a prime choice for investigation of folding defects of recombinant proteins expressed in the cytoplasm, it is typically unable to overcome bottlenecks associated with periplasmic production.

\section{Overproduction of Hsp60 and Hsp70 members with membrane proteins}

Recombinant production of membrane proteins in E. coli presents very particular and complex challenges to the bacterial host. There are few reports of co-production of molecular chaperones with membrane proteins in E. coli due to the paucity of reports of recombinant membrane protein produced successfully in the host in general. Amongst these, the expression and solubility of the HrcA repressor from Helicobacter pylori were dramatically increased upon induction of heat shock proteins by elevated temperature [109] while overexpression of GroESL led to significantly improved expression of the human liver cytochrome P450 2B6 [110] and a DnaK-DnaJ combination reduced inclusion body formation by the CorA bacterial magnesium transporter [66]. While the present body of literature does not make a particularly compelling case for adding chaperones to membrane protein production experiments in E. coli, screening of their influence in such set-ups is clearly advisable due to the simplicity and low cost of the approach, and their potential benefits on the passage through the cytoplasm and/or periplasm of these often highly hydrophobic and difficult-to-express proteins.

\section{Small heat shock proteins}

Small heat shock proteins (sHsps) are a ubiquitous group of proteins that tend to exist in vivo as macromolecular complexes, the stoichiometry of which varies between different sHsps (reviewed in [111]). They bind non-native proteins with a high degree of promiscuity in an ATPindependent manner and their slowness of substrate release has led to speculation that they may function primarily as reservoirs of unfolded protein in times of stress. It is also likely that, upon removal of the physiological stress, they interact with other chaperones such as the Hsp70 group, leading to peptide release and ATP-dependent folding $[111,112]$. Their native activity has led to some interest recently in their potential usefulness in increasing the solubility of heterologous proteins in $E$. coli.

E. coli IbpA and IbpB have been demonstrated to protect misfolded proteins from irreversible aggregation and are thought to help to resolubilise protein aggregates [113$115]$. Overproduction of IbpAB led to increased production of $E$. coli malic enzyme, enhanced green fluorescent protein, and human IGF-I $\mathrm{f}_{\mathrm{f}}$ interferon $\gamma$ and interleukin$12 \beta$ chain by 1.3 - to 2 -fold in the E. coli cytoplasm [116], as well as increased soluble yields of 17 of 23 proteins, many difficult to express, in an extensive investigation of overproduction of the entire network of major E. coli cytosolic chaperones ([47] see also [46]). Increased yields of soluble proteins were also obtained upon co-overproduction of IbpAB with DnaK-DnaJ-GrpE, ClpB and GroESL, albeit only to levels attainable upon addition of the heat shock-inducer benzyl alcohol [117]. Conversely, overproduction of IbpAB could not suppress inclusion body formation by preS2-S'- $\beta$-galactosidase [118], while successful production of a human GTPase activating protein, which led to cell lysis under standard expression conditions, could be achieved only in a $\triangle i b p A B E$. coli strain [119]. Co-production of hexadecameric murine Hsp25, meanwhile, fused to an ompA signal peptide, increased the amount of functional tPA variant in the E. coli periplasm by 125 -fold [51] but there was no increase in the periplasmic yield of native proinsulin in the same study.

de Marco and co-workers recently presented an extensive evaluation of the effects of coproduction of IbpAB in association with Hsp70, Hsp60 and ClpB proteins $[46,47]$. In their approach, protein production (and chaperone coproduction) was followed by a period of inhibition of protein synthesis to allow chaperone-mediated refolding of misfolded or aggregated polypeptides. The overall effect of co-overproduction of IbpAB was an increase in the solubility of 20 of 23 proteins tested, including 12 that could not be produced in soluble form in the absence of IbpAB [47]. 


\section{Miscellaneous accessory molecules}

In additional to "conventional" chaperones, the ability of a variety of accessory proteins to improve recombinant protein production and/or activity in E. coli has been evaluated. One of the most common of these is thioredoxin (Trx), as discussed later in the context of disulfide bond metabolism. ClpB, meanwhile, is a large, star-shaped hexameric molecule that interacts with the DnaK chaperone system in a currently unresolved manner to disaggregate insoluble polypeptide aggregates (reviewed in [120]). It is postulated to unfold and pass polypeptides through its central, 13-Å channel $[121,122]$ and is an obvious candidate for overproduction given its recognised ability to disaggregate polypeptide aggregates. This potential is borne out by the observation that, while various combinations of Hsp60 and Hsp70 proteins could dissolve macromolecular aggregates of human basic fibroblast growth factor, this typically was not concomitant with increased solubility of the target unless $\mathrm{ClpB}$ was also overproduced [44]. Overproduction of tRNA molecules specific for $E$. coli rare codons, often carried out in combination with conventional chaperone co-production, has also been commonly used to increase yields of proteins from species with a codon bias significantly different from that of $E$. coli, including archaeabacteria [77], Plasmodium [123], viruses [124] and eukaryotes [125].

A further approach to chaperoning heterologous proteins in E. coli is to provide their native chaperone or accessory protein where possible, as in the case of co-production of the rubisco-specific chaperone RbcX with Synechococcus ribulose-1,5-biphosphate carboxylase/oxygenase [126]. The activity of $17 \alpha$-hydroxylase- $\mathrm{C}_{17,20}$-lyase (P450cl7) also increased 100-fold upon co-production of rat NADPH-cytochrome-P450-reductase [127] while the solubility of human retinoic acid receptor [128] and $\alpha$-subunits of human haemoglobin [129] increased upon coproduction of their binding partner and specific stabilising chaperone, respectively.

\section{Secretion from the cytoplasm}

Proteins destined for the non-reducing environment of the periplasm are most commonly secreted using the Sec (secretion) family [130]. Cytosolic SecB associates with unfolded proteins in an ATP-independent manner and delivers them to SecA, the site of preprotein entry into the membrane-bound translocase $[131,132]$. Translocation is achieved through the SecEY complex, which forms a pore through which the preprotein passes [133,134], and involves the action of SecG, which "lubricates" the pore for insertion of a SecA domain $[133,135])$ and SecD and SecF, which prevent reverse translocation of the preprotein [133].
In addition to the sec pathway, a less well characterised twin-arginine translocation (tat) pathway of membrane translocation also exists [136]. The essential components of this pathway are the Tat $\mathrm{A}, \mathrm{TatB}$ and TatC integral membrane proteins, which recognise a critical twin arginine motif in the N-terminal signal sequence of polypeptide substrates. Unlike the sec system, the Tat pathway can transport proteins across the cytoplasmic membrane in a fully folded state (Figure 2; [136,137]). Furthermore, two distinct systems, the first employing a homologue of the eukaryotic signal recognition particle called the fifty-four homologue (Ffh; [138]) and its FtsY receptor and the second the $61-\mathrm{kDa}$ cytoplasmic protein YidC [139], are involved primarily in targeting integral membrane (pre)proteins to the inner membrane in E. coli. The possible membrane translocation routes of recombinant polypeptides, and their subsequent folding in the periplasm, are represented in Figure 2.

\section{Improving the process of secretion}

While manipulation of the Sec pathway initially concentrated largely on the SecEY tranlocase, the disappointing results led to most studies focussing instead on the SecA and $\mathrm{SecB}$ proteins that deliver polypeptides to the translocase. Even then, results remained unspectacular: SecB overproduction resulted in increased solubility and a higher yield of a penicillin acylase, though enzyme activity was not increased [140], while SecB and SecF overproduction led to 3- and 2-fold increases, respectively, in the periplasmic activity of a penicillin amidase [141].

Comparatively little analysis of tat gene overexpression has been carried out, though overexpression of tat $A B C$, in combination with manipulation of physiological conditions, led to a 20-fold increase in the level of a green fluorescent protein that otherwise rapidly saturates the tat translocation machinery [142]. Co-expression of phage shock protein A (PspA) can also relieve saturation of protein export via this pathway [143] while Han and coworkers [116] demonstrated that knocking out the sHsps IbpA and IbpB led to enhanced secretion of enhanced green fluorescent protein (EGFP) from Aequorea victoria via both the sec and tat secretion pathways. The recent demonstration that DnaK and SlyD chaperones serve as general Tat signal-binding proteins [144,145], in tandem with the promising outcomes of the limited investigation of the pathway to date, is likely to focus increased attention on using the tat machinery to improve periplasmic expression over the coming years.

Meanwhile, in the only evaluation of Ffh overproduction reported to date, co-overexpression of $f f h / f f s$ (the latter encoding 4.5S RNA) or $f f h / f f s / f t s Y$ with the bacterial inner membrane magnesium transporter CorA led to reduced 


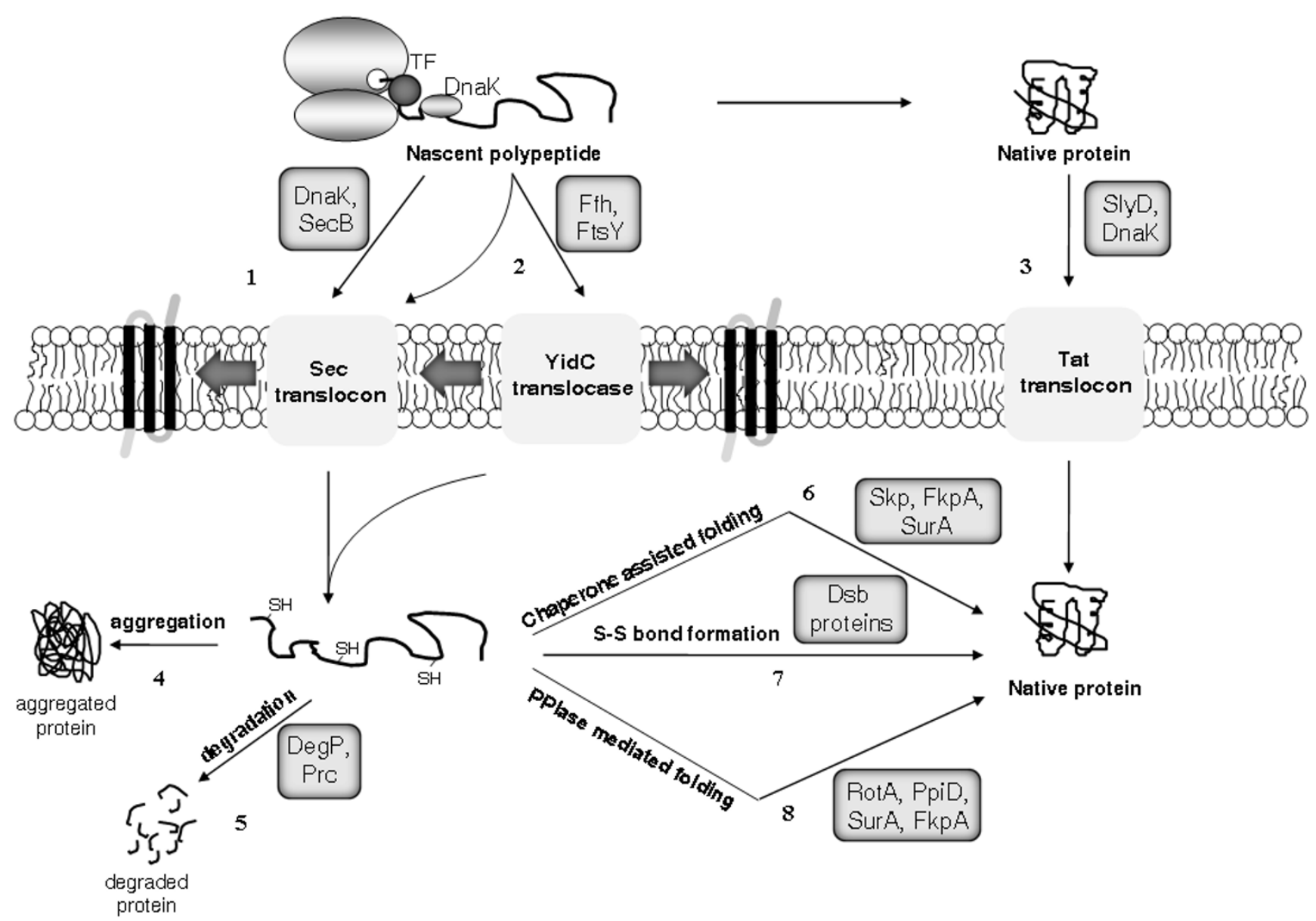

\section{Figure 2}

Membrane translocation and periplasmic folding in E. coli. Most polypeptides cross the cytoplasmic membrane in an unfolded conformation using the Sec translocase (I), following delivery to SecA at the inner surface of the membrane by DnaK or SecB chaperones. Polypeptides with highly hydrophobic signal sequences or transmembrane domains may, however, be recognised by Ffh which, together with its FtsY receptor, can target the polypeptide to either the Sec machinery or to the YidC translocase (2). Alternatively, the twin-arginine translocation (Tat) machinery is responsible for the translocation of already folded proteins (3), typically with bound metal cofactors. After cleavage of the leader peptide upon crossing the membrane, partially folded proteins may (4) aggregate, (5) be degraded by periplasmic proteases, or fold into their native state, often with the assistance of periplasmic chaperones (6) and/or folding catalysts such as disulfide bond metabolising enzymes (7) or peptidyl-prolyl cis-trans isomerases (8).

expression of CorA and failed to prevent inclusion body formation [66].

Overall, while E. coli strains that allow formation of disulfide bridges in the cytoplasm are now available, thus negating the need for secretion of disulfide-containing recombinant proteins, there is little evidence that the secretion process limits the production of most heterologous proteins. Instead, the bottleneck for production is usually more likely to involve maintenance of polypep- tides in a non-aggregated, translocation-competent form in the cytoplasm or in avoidance of aggregation in the periplasm subsequent to membrane translocation.

\section{Folding in the periplasm}

Following membrane translocation, folding of the heterologous polypeptide takes place in the periplasmic space (Figure 2). While disulfide bond formation and peptidylprolyl cis-trans isomerisation can occur here, no general molecular chaperones that prevent non-productive fold- 
ing reactions had been identified until relatively recently, when a variety of molecules such as Skp, FkpA, SurA and DegP were independently isolated and characterised.

Skp is an E. coli periplasmic seventeen kiloDalton protein that has been found to assist the production of difficultto-express antibody fragments in particular. Skp co-production led to delayed cell lysis and improved production of single-chain antibody fragments (scAbs; [146]), higher yields and increased antigen binding activity of scFvs [147], improved functional production of phage-displayed scFvs [148] and improved production and secretion of a Fab fragment [149]. Meanwhile, a signal sequence-less Skp has also been used to increase the yield of active Fab fragment in the cytoplasm of an E. coli Origami strain [19]. Skp co-production has also been utilised, in combination with protein engineering, to achieve highlevel secretion of three single-chain T cell receptors [150], which, though structurally similar to antibody fragments, have traditionally proven difficult to produce in active form in E. coli. Skp has been also found to enhance the $E$. coli cell surface display of a yellow fluorescence protein by reducing the extracytoplasmic stress and, thus, improving cell physiology [151].

DegP is a periplasmic protease that is proposed to undergo a shift to function as a chaperone at low temperatures, though it has recently been demonstrated to retain proteolytic activity as low as $20^{\circ} \mathrm{C}$ [152]. It is active in the same pathway as Skp, with SurA active in a parallel chaperone pathway. DegP overproduction has been found to reduce inclusion body formation in the periplasm and to increase the activity of penicillin acylase in E. coli $[153,154]$, while SurA and FkpA chaperones possess PPIase activity in addition to their chaperone functions and are discussed later.

\section{Manipulation of the disulfide bond metabolic machinery}

Formation of stable disulfide bonds is confined to the oxidising periplasmic environment in E. coli, where disulfide bond formation, reduction and isomerisation are catalysed by the Dsb (disulfide bond formation) family in a thiol-disulfide exchange between their active site Cys-X-XCys cysteines and those of the target protein (reviewed in [155]). DsbA catalyses disulfide bond formation by transferring its own active site disulfide to the target protein, leaving DsbA in a reduced form, whereupon it is reoxidised by the cytoplasmic membrane-bound DsbB. DsbB in turn passes its electrons to the respiratory chain to regenerate its own oxidised state. "Shuffling", or isomerisation, of incorrectly-formed disulfide pairs is carried out by DsbC, which is maintained in its reduced form by the cytoplasmic membrane-bound DsbD [156,157]. Other Dsb proteins in E. coli include DsbE, which is required for cytochrome c biogenesis, and DsbG, which catalyses disulfide bond formation but is an inefficient catalyst of disulfide rearrangement.

DsbA and DsbC in particular are commonly co-produced with disulfide-linked recombinant proteins in the periplasm, an approach which has met with considerable success. DsbA overproduction has led to increased functional yields of numerous proteins, such as heat-labile enterotoxins [158], as well as increased solubility of human leptin [159] and cyclohexanone monooxygenase [35]. DsbC has now become the Dsb protein of choice, however, particularly when producing proteins with complex disulfide patterns such as tissue plasminogen activator $[160,161]$ or Ragi bifunctional inhibitor [162], due to its potential to rescue misfolded or partially aggregated polypeptide through its isomerisation activity. In one of the few direct comparisons of the effects of the two enzymes, the expression level of insulin-like growth factor-I increased 2-fold and 1.7-fold, respectively, with DsbA and DsbC [163]. Zhang and co-workers [164] also reported improved solubility of a diverse range of eukaryotic proteins upon fusion with a DsbA variant lacking active site cysteine residues, however, which raises the question of whether Dsb proteins aid expression of recombinant proteins due to their catalytic properties or - as often in the case of PPIases (see below) - due to a chaperoning capability.

Co-production of DsbBD, DsbAB and DsbAC pairs also all led to higher functional yields of glutamate racemase (GluR; [86]) - despite the fact that GluR, while possessing 5 cysteine thiol groups, contains no disulfide bridges in its native structure. Conversely, expression of human nerve growth factor [165], horseradish peroxidase [105,166] and brain-derived neurophilic factor [167] are all more efficient in the presence of DsbABCD than individual or pairs of family members.

A number of examples also exist in the literature of coproduction of thioredoxin (Trx), a small (12 $\mathrm{kDa}$ ) protein with a Cys-X-X-Cys active site motif, which too is typically co-produced with cysteine-rich polypeptides. This approach allowed functional production of a snake venom thrombin-like enzyme, which in the absence of Trx was not detectable in the cytoplasm [168], while Trx also dramatically increased the solubility of mouse c-Myb, CAMP response element-binding protein 1, p53 tumour suppressor gene product, adenovirus oncogene product E1A, Xenopus mos proto-oncogene product and the tyrosine kinase Lck, all of which were otherwise produced in inclusion bodies [65]. Thioredoxin co-production has also been demonstrated to increase by $3-4$ fold the yield of functional ribotoxin $\alpha$-sarcin in the E. coli periplasm [169]. In addition to its use as a separate, co-produced protein, thioredoxin is commonly employed as a fusion 
tag to improve the expression or solubility of heterologous proteins.

While stable disulfide bridges cannot normally be formed in the strongly reducing E. coli cytoplasm, there are increasing attempts to produce disulfide-containing heterologous proteins there, usually by blocking either or both of the thioredoxin/thioredoxin reductase and glutathione/glutaredoxin reducing pathways. Co-expression of a leaderless $d s b C$ in such an E. coli background has greatly enhanced production of antibody fragments [19] and of proteins with complex disulfide patterns, such as tPA [161], thrombin-like enzyme calobin [168] and snake venom fibrolase [170], such that screening of production of cysteine-rich recombinant proteins that are particularly prone to aggregation is well-advised in E. coli trx or gor mutant strains.

\section{Overproduction of periplasmic PPlases}

PPIases exist in three distinct families in E. coli: cyclophilins, whose isomerase (rotamase) activity is reversibly inhibited by cyclosporin A and which are thought to be essential in processes such as protein folding and subcellular trafficking; FKBPs (FK506 binding proteins), which are inhibited by FK506 and rapamycin and include the periplasmic FkpA and cytoplasmic metal-binding SlyD and trigger factor (discussed above), which is novel amongst FKBPs in exhibiting no affinity for FK506; and parvulins, including the periplasmic SurA and membranebound PpiD, which are insensitive to immunosuppressors but irreversibly inhibited by juglone and have roles in the folding of outer membrane proteins [10]. The three families exhibit limited sequence and structural similarity but share a high catalytic activity and a relatively low affinity for nonstructured peptides [171].

Of the 4 PPIases identified in the E. coli periplasm - PpiA (RotA), PpiD, FkpA and SurA - mutations in PpiA have been shown to have no effect on the folding of periplasmic and outer membrane proteins [172] and PpiA overproduction has failed to improve expression of $\mathrm{scFv}$ fragments or a single-chain TcR $[173,174]$. There have been no reports of overproduction of PpiD as an approach to improving heterologous protein production in E. coli but the recent report that it interacts with proteins exiting the SecYEG translocon [175] suggests it may be a promising target for overexpression with problematic secretory proteins. SurA, also a parvulin, was found to improve the folding of unstable or aggregation-prone proteins in the periplasm [176] but failed to help production of a scFv fragment [173]. Meanwhile FkpA, which like trigger factor possesses both chaperone and PPIase activity, enhanced production of a wide range of scFv fragments by up to 10fold when overproduced [173], while its fusion to various scAb fragments also led to increased solubility and higher functional yields [177]. FkpA co-production also led to increased hydrolysis of ampicillin by a catalytic scFv [178] and enhanced the production of penicillin acylase [179].

\section{Fusion tags}

A related approach to improving recombinant protein solubility, though outside the scope of this review, is the use of fusion tags, e.g. thioredoxin, maltose-binding protein, glutathione $S$-transferase and, more recently, E. coli stressresponsive proteins such as RpoS [180], SlyD [181], and PotD and Crr [182]. This strategy generally results in reliably high protein yields and can simplify purification due to the affinity of certain fusion partners for a particular ligand. It also leads to considerations about how the fusion partner may affect folding or activity and the requirement for its precise removal, but the general approach has met with considerable success in increasing protein solubility, as reviewed elsewhere $[183,184]$.

\section{Overview}

Though there are currently no rigid criteria by which one might identify in silico the "correct" chaperone(s) to overcome a particular bottleneck in protein production, the present review identifies the co-production strategies that have most successfully overcome the major problems limiting recombinant protein yields in E. coli to date. Based on the current state-of-the-art, therefore, we summarise in Figure 3 some targeted interventions that might be used to focus chaperone screening strategies on already proven approaches, thus increasing the chances of successful production of well-behaved, active protein.

\section{Concluding remarks}

Co-production of molecular chaperones and folding catalyst improves - very greatly in many cases - the production of many heterologous proteins in E. coli. While there is still no panacea for folding problems, nor even a rational method to identify the optimal candidate(s) for co-production with a target of interest, researchers are increasingly turning to chaperone co-production systems, available both commercially and non-commercially, as their first port of call when looking to overcome folding bottlenecks. While such a multi-chaperone screening approach can bear fruit quickly and relatively painlessly, detailed mechanistic studies of individual folding modulators remain essential in order to better understand their molecular mechanisms for greater, longer term practical benefits to the field of $E$. coli recombinant protein production.

Finally, though the merit of co-expression of some eukaryotic chaperones in E. coli is long recognised $[185,186]$, the immense potential of chaperones from extremophilic species has only recently begun to be mined. Successes to date with GroESL homologues from Oleispira antarctica [187] 


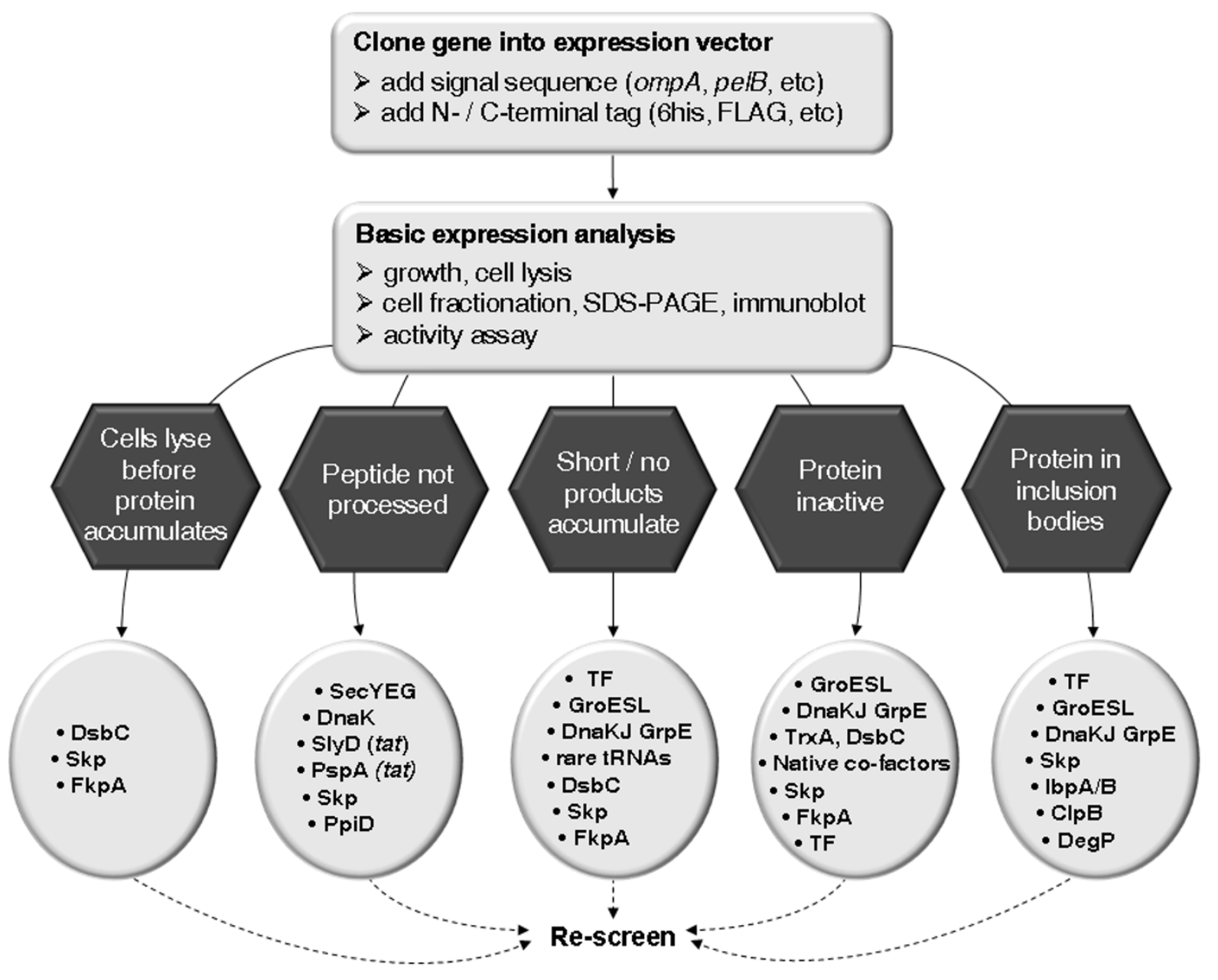

Figure 3

Strategy for selection of molecular chaperones and folding catalysts for co-production analyses. Following production of a recombinant protein in $E$. coli, analysis of cell growth, protein solubility and subcellular location, macromolecular state and activity provide some insight into the limiting step in the folding and production process. This Figure shows the major bottlenecks typically encountered (in hexagons) during production of a difficult-to-express recombinant target and identifies the co-production strategies that have been most successful in overcoming these bottlenecks to date (corresponding ovals).

and a novel trigger factor from another psychrophile, Psychrobacter frigidicola [188], suggest that these studies may represent the beginning of a new era in chaperone-assisted production of recombinant proteins in E. coli.

\section{Competing interests}

The authors declare that they have no competing interests.

\section{Authors' contributions}

All authors contributed equally to this manuscript, and read and approved the final version.

\section{Acknowledgements}

The authors gratefully acknowledge the support of grants CFTD/04/106 (to $\mathrm{OK}$ and SR) and PC/2007/02 I (to SR) from Enterprise Ireland Science and Technology Development agency and Postdoctoral Fellowship PD/2005/44 from the Irish Research Council for Science, Engineering and Technology (IRCSET; to SS).

\section{References}

I. Rai M, Padh H: Expression systems for production of heterologous proteins. Curr Science 200I, 80: | | $2 \mid-8$.

2. Spada S, Walsh G: Directory of approved biopharmaceutical products Boca Raton: CRC Press, USA; 2005.

3. Wall JG, Plückthun A: The hierarchy of mutations influencing the folding of antibody domains in Escherichia coli. Protein Eng 1999, 12:605-II.

4. Hoffmann F, Rinas U: Stress induced by recombinant protein production in Escherichia coli. Adv Biochem Eng Biotechnol 2004, 89:73-92.

5. Wall JG, Plückthun A: Effects of overexpressing folding modulators on the in vivo folding of heterologous proteins in Escherichia coli. Curr Opin Biotechnol 1995, 6:507-16.

6. Goloubinoff P, Christeller JT, Gatenby AA, Lorimer GH: Reconstitution of active dimeric ribulose bisphosphate carboxylase 
from an unfoleded state depends on two chaperonin proteins and Mg-ATP. Nature 1989, 342:884-9.

7. Goloubinoff P, Gatenby AA, Lorimer GH: GroE heat-shock proteins promote assembly of foreign prokaryotic ribulose bisphosphate carboxylase oligomers in Escherichia coli. Nature 1989, 337:44-7.

8. de Marco A, de Marco V: Bacteria co-transformed with recombinant proteins and chaperones cloned in independent plasmids are suitable for expression tuning. J Biotechnol 2004, 109:45-52.

9. Schlapschy M, Grimm S, Skerra A: A system for concomitant overexpression of four periplasmic folding catalysts to improve secretory protein production in Escherichia coli. Protein Eng Des Sel 2006, 19:385-90.

10. Pliyev BK, Gurvits BY: Peptidyl-prolyl cis-trans isomerases: structure and functions. Biochemistry (Mosc) 1999, 64:738-5I.

II. Ferbitz L, Maier T, Patzelt H, Bukau B, Deuerling E, Ban N: Trigger factor in complex with the ribosome forms a molecular cradle for nascent proteins. Nature 2004, 43 I:590-6.

12. Merz F, Boehringer D, Schaffitzel C, Preissler S, Hoffmann A, Maier T, Rutkowska A, Lozza J, Ban N, Bukau B, Deuerling E: Molecular mechanism and structure of Trigger Factor bound to the translating ribosome. EMBO J 2008, 27:1622-32.

13. Patzelt H, Kramer G, Rauch T, Schonfeld HJ, Bukau B, Deuerling E: Three-state equilibrium of Escherichia coli trigger factor. Biol Chem 2002, 383:1611-9.

14. Liu CP, Perrett S, Zhou JM: Dimeric trigger factor stably binds folding-competent intermediates and cooperates with the DnaK-DnaJ-GrpE chaperone system to allow refolding. J Biol Chem 2005, 280:13315-20.

15. Teter SA, Houry WA, Ang D, Tradler T, Rockabrand D, Fischer G, Blum P, Georgopoulos C, Hartl FU: Polypeptide flux through bacterial Hsp70: DnaK cooperates with trigger factor in chaperoning nascent chains. Cell 1999, 97:755-65.

16. Scholz C, Stoller G, Zarnt T, Fischer G, Schmid FX: Cooperation of enzymatic and chaperone functions of trigger factor in the catalysis of protein folding. EMBO | 1997, 16:54-8.

17. Nishihara K, Kanemori M, Yanagi H, Yura T: Overexpression of trigger factor prevents aggregation of recombinant proteins in Escherichia coli. Appl Environ Microbiol 2000, 66:884-9.

18. Kramer G, Patzelt H, Rauch T, Kurz TA, Vorderwulbecke S, Bukau B, Deuerling E: Trigger factor peptidyl-prolyl cis/trans isomerase activity is not essential for the folding of cytosolic proteins in Escherichia coli. J Biol Chem 2004, 279:14165-70.

19. Levy R, Weiss R, Chen G, Iverson BL, Georgiou G: Production of correctly folded Fab antibody fragment in the cytoplasm of Escherichia coli trxB gor mutants via the coexpression of molecular chaperones. Protein Expr Purif 200I, 23:338-47.

20. Ito T, Wagner G: Using codon optimization, chaperone coexpression, and rational mutagenesis for production and NMR assignments of human elF2 alpha. J Biomol NMR 2004, 28:357-67.

21. Yoshimune K, Ninomiya Y, Wakayama M, Moriguchi M: Molecular chaperones facilitate the soluble expression of $\mathbf{N}$-acyl-Damino acid amidohydrolases in Escherichia coli. J Ind Microbiol Biotechnol 2004, 31:42I-6.

22. Ikura K, Kokubu T, Natsuka S, Ichikawa A, Adachi M, Nishihara K, Yanagi $H$, Utsumi S: Co-overexpression of folding modulators improves the solubility of the recombinant guinea pig liver transglutaminase expressed in Escherichia coli. Prep Biochem Biotechnol 2002, 32:189-205.

23. Sun QM, Cao L, Fang L, Chen C, Dai J, Chen LL, Hua ZC: Expression, purification of human vasostatin $120-180$ in Escherichia coli, and its anti-angiogenic characterization. Protein Expr Purif 2005, 39:288-95.

24. Kandror $\mathrm{O}$, Goldberg AL: Trigger factor is induced upon cold shock and enhances viability of Escherichia coli at low temperatures. Proc Natl Acad Sci USA 1997, 94:4978-8I.

25. Li ZY, Liu CP, Zhu LQ, Jing GZ, Zhou JM: The chaperone activity of trigger factor is distinct from its isomerase activity during co-expression with adenylate kinase in Escherichia coli. FEBS Lett 200I, 506:108-12.

26. Ideno A, Furutani M, Iwabuchi T, lida T, Iba $Y$, Kurosawa $Y$, Sakuraba $H$, Ohshima T, Kawarabayashi $Y$, Maruyama T: Expression of foreign proteins in Escherichia coli by fusing with an archaeal FK506 binding protein. Appl Microbiol Biotechnol 2004, 64:99-105.
27. Gragerov A, Zeng L, Zhao X, Burkholder W, Gottesman ME: Specificity of DnaK-peptide binding. J Mol Biol 1994, 235:848-54.

28. Rudiger S, Germeroth L, Schneider-Mergener J, Bukau B: Substrate specificity of the DnaK chaperone determined by screening cellulose-bound peptide libraries. EMBO J 1997, 16:150I-7.

29. Hartl FU, Martin J: Molecular chaperones in cellular protein folding. Curr Opin Struct Biol 1995, 5:92-102.

30. Wall D, Zylicz M, Georgopoulos C: The NH2-terminal 108 amino acids of the Escherichia coli DnaJ protein stimulate the ATPase activity of DnaK and are sufficient for lambda replication. J Biol Chem 1994, 269:5446-5 I.

31. Szabo A, Korszun R, Hartl FU, Flanagan J: A zinc finger-like domain of the molecular chaperone DnaJ is involved in binding to denatured protein substrates. EMBO J 1996, 15:408-17.

32. Szabo A, Langer T, Schroder H, Flanagan J, Bukau B, Hartl FU: The ATP hydrolysis-dependent reaction cycle of the Escherichia coli Hsp70 system DnaK, DnaJ, and GrpE. Proc Natl Acad Sci USA 1994, $91: 10345-9$.

33. Choi GH, Lee DH, Min WK, Cho YJ, Kweon DH, Son DH, Park K, Seo $\mathrm{JH}$ : Cloning, expression, and characterization of singlechain variable fragment antibody against mycotoxin deoxynivalenol in recombinant Escherichia coli. Protein Expr Purif 2004, 35:84-92.

34. Caspers P, Stieger M, Burn P: Overproduction of bacterial chaperones improves the solubility of recombinant protein tyrosine kinases in Escherichia coli. Cell Mol Biol (Noisy-le-grand) 1994 40:635-44.

35. Lee DH, Kim MD, Lee WH, Kweon DH, Seo JH: Consortium of fold-catalyzing proteins increases soluble expression of cyclohexanone monooxygenase in recombinant Escherichia coli. Appl Microbiol Biotechnol 2004, 63:549-52.

36. Nishihara K, Kanemori M, Kitagawa M, Yanagi H, Yura T: Chaperone coexpression plasmids: Differential and synergistic roles of DnaK-DnaJ-GrpE and GroEL-GroES in assisting folding of an allergen of Japanese cedar pollen, Cryj2 in Escherichia coli. Appl Environ Microb 1998, 64:1694-9.

37. Yokoyama K, Kikuchi Y, Yasueda H: Overproduction of DnaJ in Escherichia coli improves in vivo solubility of the recombinant fish-derived transglutaminase. Biosci Biotechnol Biochem 1998, 62:1205-10.

38. Schneider EL, Thomas JG, Bassuk JA, Sage EH, Baneyx F: Manipulating the aggregation and oxidation of human SPARC in the cytoplasm of Escherichia coli. Nat Biotechnol 1997, 15:58I-5.

39. Chao YP, Chiang CJ, Lo TE, Fu H: Overproduction of D-hydantoinase and carbamoylase in a soluble form in Escherichia coli. Appl Microbiol Biotechnol 2000, 54:348-53.

40. Thomas JG, Baneyx F: Protein misfolding and inclusion body formation in recombinant Escherichia coli cells overexpressing Heat-shock proteins. J Biol Chem 1996, 27 I: I I I I-7.

41. González-Montálban N, García-Fruitós E, Villaverde A: Recombinant protein solubility - does more mean better? Nat Biotechnol 2007, 25:718-20.

42. García-Fruitós E, Martínez-Alonso M, González-Montálban N, Valli M, Mattanovich D, Villaverde A: Divergent genetic control of protein solubility and conformational quality in Escherichia coli. I Mol Biol 2007, 374: 195-205.

43. Watanabe K, Fujiwara H, Inui K, Suzuki Y: Oligo-I,6-glucosidase from a thermophile, Bacillus thermoglucosidasius KP was efficiently produced by combinatorial expression of GroEL in Escherichia coli. Biotechnol Appl Biochem 1006, 35:35-43.

44. Rinas U, Hoffmann F, Betiku E, Estapé D, Marten S: Inclusion body anatomy and functioning of chaperone-mediated in vivo inclusion body disassembly during high-level recombinant protein production in Escherichia coli. | Biotechnol 2007, 1 27:244-57.

45. Xu HM, Zhang GY, Ji XD, Cao L, Shu L, Hua ZC: Expression of soluble, biologically active recombinant human endostatin in Escherichia coli. Protein Expr Purif 2005, 41:252-8.

46. de Marco A: Protocol for preparing proteins with improved solubility by co-expressing with molecular chaperones in Escherichia coli. Nat Protoc 2007, 2:2632-9.

47. de Marco A, Deuerling E, Mogk A, Tomoyasu T, Bukau B: Chaperone-based procedure to increase yields of soluble recombinant proteins produced in E. coli. BMC Biotechnol 2007, 7:32.

48. Hu X, O'Hara L, White S, Magner E, Kane M, Wall JG: Optimisation of production of a domoic acid-binding scFv antibody frag- 
ment in Escherichia coli using molecular chaperones and functional immobilisation on a mesoporous silicate support. Protein Expr Purif 2007, 52:194-201.

49. Pérez-Pérez J, Martínez-Caja C, Barbero JL, Gutiérrez J: DnaK/DnaJ supplementation improves the periplasmic production of human granulocyte-colony stimulating factor in Escherichia coli. Biochem Biophys Res Commun 1995, 2 1 0:524-9.

50. Bergès $H$, Joseph-Liauzun $E$, Fayet $O$ : Combined effects of the signal sequence and the major chaperone proteins on the export of human cytokines in Escherichia coli. Appl Environ Microbiol 1996, 62:55-60.

5I. Schaffner J, Winter J, Rudolph R, Schwarz E: Cosecretion of chaperones and low-molecular-size medium additives increases the yield of recombinant disulfide-bridged proteins. Appl Environ Microbiol 200I, 67:3994-4000.

52. Braig K, Otwinowski Z, Hegde R, Boisvert DC, Joachimiak A, Horwich AL, Sigler PB: The crystal structure of the bacterial chaperonin GroEL at 2.8 A. Nature 1994, 371:578-86.

53. Sigler PB, Xu Z, Rye HS, Burston SG, Fenton WA, Horwich AL: Structure and function in GroEL-mediated protein folding. Annu Rev Biochem 1998, 67:581-608.

54. Chapman E, Farr GW, Usaite R, Furtak K, Fenton WA, Chaudhuri TK, Hondorp ER, Matthews RG, Wolf SG, Yates JR, Pypaert M, Horwich AL: Global aggregation of newly translated proteins in an Escherichia coli strain deficient of the chaperonin GroEL. Proc Natl Acad Sci USA 2006, I 03: I 5800-5.

55. Hunt JF, Weaver AJ, Landry SJ, Gierasch L, Deisenhofer J: The crystal structure of the GroES co-chaperonin at $2.8 \AA$ resolution. Nature 1996, 379:37-45.

56. Chen DH, Song JL, Chuang DT, Chiu W, Ludtke SJ: An expanded conformation of single-ring GroEL-GroES complex encapsulates an 86 kDa substrate. Structure 2006, | 4: |7| |-22.

57. Todd MJ, Lorimer GH, Thirumalai D: Chaperonin-facilitated protein folding: optimization of rate and yield by an iterative annealing mechanism. Proc Natl Acad Sci USA 1996, 93:4030-5.

58. Chaudhuri TK, Farr GW, Fenton WA, Rospert S, Horwich AL GroEL/GroES-mediated folding of a protein too large to be encapsulated. Cell 200I, I07:235-46.

59. Chaudhuri TK, Verma VK, Maheshwari A: GroEL assisted folding of large polypeptide substrates in Escherichia coli: Present scenario and assignments for the future. Prog Biophys $\mathrm{Mol} B i o l$ 2008.

60. Hsu PY, Tsai AL, Kulmacz RJ, Wang LH: Expression, purification, and spectroscopic characterization of human thromboxane synthase. I Biol Chem 1999, 274:762-9.

6I. Yanase H, Moriya K, Mukai N, Kawata Y, Okamoto K, Kato N: Effects of GroESL coexpression on the folding of nicotinoprotein formaldehyde dismutase from Pseudomonas putida F6 I. Biosci Biotechnol Biochem 2002, 66:85-91.

62. Carvalho H, Meneghini R: Increased expression and purification of soluble iron-regulatory protein I from Escherichia coli coexpressing chaperonins GroES and GroEL. Braz J Med Biol Res 2008, 41:270-6.

63. Xie L, Chatterjee C, Balsara R, Okeley NM, Donk WA van der: Heterologous expression and purification of SpaB involved in subtilin biosynthesis. Biochem Biophys Res Commun 2002 295:952-7.

64. Machida S, Yu Y, Singh SP, Kim JD, Hayashi K, Kawata Y: Overproduction of beta-glucosidase in active form by an Escherichic coli system coexpressing the chaperonin GroEL/ES. FEMS Microbiol Lett 1998, 159:41-6.

65. Yasukawa T, Kanei-Ishii C, Maekawa T, Fujimoto J, Yamamoto T, Ishii $\mathrm{S}$ : Increase of solubility of foreign proteins in Escherichia coli by coproduction of the bacterial thioredoxin. J Biol Chem I995, 270:25328-3I.

66. Chen Y, Song J, Sui SF, Wang DN: DnaK and DnaJ facilitated the folding process and reduced inclusion body formation of magnesium transporter CorA overexpressed in Escherichia coli. Protein Expr Purif 2003, 32:221-31.

67. Shapir N, Pedersen C, Gil O, Strong L, Seffernick J, Sadowsky MI Wackett LP: TrzN from Arthrobacter aurescens TCI Is a zinc amidohydrolase. J Bacteriol 2006, I 88:5859-64.

68. Lee SC, Olins PO: Effect of overproduction of heat shock chaperones GroESL and DnaK on human procollagenase production in Escherichia coli. J Biol Chem 1992, 267:2849-52.
69. Amrein KE, Takacs B, Stieger M, Molnos J, Flint NA, Burn P: Purification and characterization of recombinant human p50csk protein-tyrosine kinase from an Escherichia coli expression system overproducing the bacterial chaperones GroES and GroEL. Proc Natl Acad Sci USA 1995, 92:1048-52.

70. Proudfoot AE, Goffin L, Payton MA, Wells TN, Bernard AR: In vivo and in vitro folding of a recombinant metalloenzyme, phosphomannose isomerase. Biochem J 1996, 3 I 8(Pt 2):437-42.

7I. Kelson TL, Ohura T, Kraus JP: Chaperonin-mediated assembly of wild-type and mutant subunits of human propionyl-CoA carboxylase expressed in Escherichia coli. Hum Mol Genet 1996, 5:331-7.

72. Salazar D, Zhang L, deGala GD, Frerman FE: Expression and characterization of two pathogenic mutations in human electron transfer flavoprotein. I Biol Chem 1997, 272:26425-33.

73. Luo ZH, Hua ZC: Increased solubility of glutathione S-transferase-PI6 (GST-p I6) fusion protein by co-expression of chaperones groes and groel in Escherichia coli. Biochem Mol Biol Int 1998, 46:47|-7.

74. Baedeker M, Schulz GE: Overexpression of a designed 2.2 kb gene of eukaryotic phenylalanine ammonia-lyase in Escherichia coli. FEBS Lett 1999, 457:57-60.

75. Vonrhein C, Schmidt U, Ziegler GA, Schweiger S, Hanukoglu I, Schulz GE: Chaperone-assisted expression of authentic bovine adrenodoxin reductase in Escherichia coli. FEBS Lett 1999 , 443: I67-9.

76. Wisen S, Jiang F, Bergman B, Mannervik B: Expression and purification of the transcription factor NtcA from the cyanobacterium Anabaena PCC 7120. Protein Expr Purif 1999, 17:351-7.

77. Imamura $\mathrm{H}$, Jeon $\mathrm{B}$, Wakagi $\mathrm{T}$, Matsuzawa $\mathrm{H}$ : High level expression of Thermococcus litoralis 4-alpha-glucanotransferase in a soluble form in Escherichia coli with a novel expression system involving minor arginine tRNAs and GroELS. FEBS Lett I999, 457:393-6.

78. Inoue E, Takahashi Y, Imai Y, Kamataki T: Development of bacterial expression system with high yield of CYP3A7, a human fetus-specific form of cytochrome P450. Biochem Biophys Res Commun 2000, 269:623-7.

79. Wynn RM, Davie JR, Song JL, Chuang JL, Chuang DT: Expression of El component of human branched-chain alpha-keto acid dehydrogenase complex in Escherichia coli by cotransformation with chaperonins GroEL and GroES. Methods Enzymol 2000, 324:|79-9|.

80. de Marco A, Volrath S, Bruyere T, Law M, Fonne-Pfister R: Recombinant maize protoporphyrinogen IX oxidase expressed in Escherichia coli forms complexes with GroEL and DnaK chaperones. Protein Expr Purif 2000, 20:8I-6

8I. Mizobata T, Kagawa M, Murakoshi N, Kusaka E, Kameo K, Kawata Y, Nagai J: Overproduction of Thermus sp. YS 8-13 manganese catalase in Escherichia coli production of soluble apoenzyme and in vitro formation of active holoenzyme. Eur J Biochem 2000, 267:4264-7I.

82. Maier G, Manakova E, Heumann H: Effect of Escherichia coli chaperonin GroELS on heterologously expressed human immunodeficiency virus type I reverse transcriptase in vivo and in vitro. Appl Biochem Biotechnol 2000, 87:103-I5.

83. Sareen D, Sharma R, Vohra RM: Chaperone-assisted overexpression of an active D-carbamoylase from Agrobacterium tumefaciens AM 10. Protein Expr Purif 200I, 23:374-9.

84. Goenka S, Rao CM: Expression of recombinant zeta-crystallin in Escherichia coli with the help of GroEL/ES and its purification. Protein Expr Purif 200 I, 2 I:260-7.

85. Nakayama N, Matsubara T, Ohshiro T, Moroto Y, Kawata Y, Koizumi K, Hirakawa Y, Suzuki M, Maruhashi K, Izumi Y, Kurane R: A novel enzyme, 2'-hydroxybiphenyl-2-sulfinate desulfinase (DszB), from a dibenzothiophene-desulfurizing bacterium $R$ hodococcus erythropolis KA2-5-I: gene overexpression and enzyme characterization. Biochim Biophys Acta 2002, I 598: I 22-30.

86. Kohda J, Endo Y, Okumura N, Kurokawa Y, Nishihara K, Yanagi H, Yura $\mathrm{T}$, Fukuda $\mathrm{H}$, Kondo $\mathrm{A}$ : Improvement of productivity of active form of glutamate racemase in Escherichia coli by coexpression of folding accessory proteins. Biochem Eng J 2002, 1 0:39-45.

87. George RR, Harris R, Nunn CM, Cramer R, Djordjevic S: Chaperonin assisted overexpression, purification, and characterisa- 
tion of human PP2A methyltransferase. Protein Expr Purif 2002, 26:266-74

88. Kwon MJ, Park S-L, Kim S-K, Nam S-W: Overproduction of Bacillus macerans cyclodextrin glucanotransferase in $E$. coli by coexpression of GroEL/ES chaperone. I Microbiol Biotechnol 2002, I 2: 1002-5

89. Park SL, Kwon M-J, Kim S-K, Nam S-W: GroEL/ES chaperone and low temperature synergistically enhanced the soluble expression of CGTase in E. coli. J Microbiol Biotechnol 2004, 14:216-9.

90. Bastida A, Latorre M, Garcia-Junceda E: In vivo chaperone-assisted folding of alpha-I,6-fucosyltransferase from Rhizobium sp. Chembiochem 2003, 4:531-3.

91. Uchida E, Kagawa N, Sakaki T, Urushino N, Sawada N, Kamakura M, Ohta M, Kato S, Inouye K: Purification and characterization of mouse CYP27B I overproduced by an Escherichia coli system coexpressing molecular chaperonins GroEL/ES. Biochem Biophys Res Commun 2004, 323:505-II.

92. Yoshikane Y, Yokochi N, Ohnishi K, Yagi T: Coenzyme precursorassisted cooperative overexpression of an active pyridoxine 4-oxidase from Microbacterium luteolum. Protein Expr Purif 2004, 34:243-8.

93. Yokochi N, Yoshikane Y, Trongpanich Y, Ohnishi K, Yagi T: Molecular cloning, expression, and properties of an unusual aldoketo reductase family enzyme, pyridoxal 4-dehydrogenase, that catalyzes irreversible oxidation of pyridoxal. J Biol Chem 2004, 279:37377-84.

94. Kagawa N, Hori H, Waterman MR, Yoshioka S: Characterization of stable human aromatase expressed in E. coli. Steroids 2004, 69:235-43.

95. Heo MA, Kim SH, Kim SY, Kim YJ, Chung J, Oh MK, Lee SG: Functional expression of single-chain variable fragment antibody against c-Met in the cytoplasm of Escherichia coli. Protein Expr Purif 2006, 47:203-9.

96. Gupta P, Aggarwal N, Batra P, Mishra S, Chaudhuri TK: Co-expression of chaperonin GroEL/GroES enhances in vivo folding of yeast mitochondrial aconitase and alters the growth characteristics of Escherichia coli. Int J Biochem Cell Biol 2006, 38:1975-85.

97. Fedulova N, Hanrieder J, Bergquist J, Emren LO: Expression and purification of catalytically active human PHD3 in Escherichia coli. Protein Expr Purif 2007, 54:1-10.

98. Bottcher D, Brusehaber E, Doderer K, Bornscheuer UT: Functional expression of the gamma-isoenzyme of pig liver carboxyl esterase in Escherichia coli. Appl Microbiol Biotechnol 2007, 73:1282-9

99. Dong X, Tang B, Li J, Xu Q, Fang S, Hua Z: Expression and purification of intact and functional soybean (Glycine max) seed ferritin complex in Escherichia coli. J Microbiol Biotechnol 2008, 18:299-307.

100. Zollner A, Kagawa N, Waterman MR, Nonaka Y, Takio K, Shiro Y, Hannemann F, Bernhardt R: Purification and functional characterization of human Ilbeta hydroxylase expressed in Escherichia coli. FEBS J 2008, 275:799-8I0.

101. Huang Y, Choi MY, Au SW, Au DM, Lam VM, Engel PC: Purification and detailed study of two clinically different human glucose 6-phosphate dehydrogenase variants, G6PD(Plymouth) and G6PD(Mahidol): Evidence for defective protein folding as the basis of disease. Mol Genet Metab 2008, 93:44-53.

102. Han KG, Lee SS, Kang C: Soluble expression of cloned phage KI I RNA polymerase gene in Escherichia coli at a low temperature. Protein Expr Purif 1999, 16:103-8.

103. Zhang Z, Li ZH, Wang F, Fang M, Yin CC, Zhou ZY, Lin Q, Huang HL: Overexpression of DsbC and DsbG markedly improves soluble and functional expression of single-chain Fv antibodies in Escherichia coli. Protein Expr Purif 2002, 26:2 18-28.

104. Sun AL, Hua ZC, Yao J, Yang YH, Yin DQ: Fusion expression of human pro-urokinase with E. coli thioredoxin. Biochem Mol Biol Int 1998, 46:479-86.

105. Kondo A, Kohda J, Endo Y, Shiromizu T, Kurokawa Y, Nishihara K, Yanagi H, Yura T, Fukuda H: Improvement of productivity of active horseradish peroxidase in Escherichia coli by coexpression of Dsb proteins. J Biosci Bioeng 2000, 90:600-6.

106. Kim SG, Kweon DH, Lee DH, Park YC, Seo JH: Coexpression of folding accessory proteins for production of active cyclodex- trin glycosyltransferase of Bacillus macerans in recombinant Escherichia coli. Protein Expr Purif 2005, 41 :426-32.

107. Venkatesh B, Arifuzzaman M, Mori H, Taguchi T, Ohmiya Y: GroEL chaperone binding to beetle luciferases and the implications for refolding when co-expressed. Biosci Biotechnol Biochem 2004, 68:2096-103.

108. Xu Y, Weng CL, Narayanan N, Hsieh MY, Anderson WA, Scharer JM, Moo-Young M, Chou CP: Chaperone-mediated folding and maturation of the penicillin acylase precursor in the cytoplasm of Escherichia coli. Appl Environ Microbiol 2005, 7 I:6247-53.

109. Roncarati D, Spohn G, Tango N, Danielli A, Delany I, Scarlato V: Expression, purification and characterization of the membrane-associated HrcA repressor protein of Helicobacter pylori. Protein Expr Purif 2007, 5 1:267-75.

110. Mitsuda $M$, Iwasaki $M$ : Improvement in the expression of CYP2B6 by co-expression with molecular chaperones GroES/EL in Escherichia coli. Protein Expr Purif 2006, 46:40I-5.

III. Buchner J: Supervising the fold: functional principles of molecular chaperones. FASEB J 1996, 10:10-9.

II2. Ehrnsperger M, Gaestel M, Buchner J: Structure and function of small heat-shock proteins. In Molecular chaperones in the life cycle of proteins Edited by: Fink AL, Goto Y. New York: Dekker; 1998:533-75.

I 13. Mogk A, Deuerling E, Vorderwülbecke S, Vierling E, Bukau B: Small heat shock proteins, ClpB and the DnaK system form a functional triade in reversing protein aggregation. Mol Microbiol 2003, 50:585-95.

I 14. Kuczynska-Wisnik D, Zurawa-Janicka D, Narkiewicz J, Kwiatkowska J, Lipinska B, Laskowska E: Escherichia coli small heat shock proteins IbpA/B enhance activity of enzymes sequestered in inclusion bodies. Acta Biochim Pol 2004, 5 1:925-3I.

II5. Jiao W, Qian M, Li P, Zhao L, Chang Z: The essential role of the flexible termini in the temperature-responsiveness of the oligomeric state and chaperone-like activity for the polydisperse small heat shock protein IbpB from Escherichia coli. $J$ Mol Biol 2005, 347:87I-84.

I 16. Han MJ, Park SJ, Park TJ, Lee SY: Roles and applications of small heat shock proteins in the production of recombinant proteins in Escherichia coli. Biotechnol Bioeng 2004, 88:426-36.

II7. de Marco A, Vigh L, Diamant S, Goloubinoff P: Native folding of aggregation-prone recombinant proteins in Escherichia coli by osmolytes, plasmid- or benzyl alcohol-overexpressed molecular chaperones. Cell Stress Chaperones 2005, 10:329-39.

1 18. Thomas JG, Baneyx F: ClpB and HtpG facilitate de novo protein folding in stressed Escherichia coli cells. Mol Microbiol 2000, 36:1360-70

119. Ochocka AM, Czyzewska M, Pawelczyk T: Expression in Escherichia coli of human ARHGAP6 gene and purification of His-tagged recombinant protein. Acta Biochim Pol 2003, 50:239-47.

120. Doyle SM, Wickner S: Hsp I 04 and ClpB: protein disaggregating machines. Trends Biochem Sci 2009, 34:40-8.

121. Hanson PI, Whiteheart SW: AAA+ proteins: have engine, will work. Nat Rev Mol Cell Biol 2005, 6:519-29.

122. Doyle SM, Shorter J, Zolkiewski M, Hoskins JR, Lindquist S, Wickner $\mathrm{S}$ : Asymmetric deceleration of ClpB or Hspl04 ATPase activity unleashes protein-remodeling activity. Nat Struct Mol Biol 2007, 14: I | 4-22.

123. Baca AM, Hol WG: Overcoming codon bias: a method for highlevel overexpression of Plasmodium and other AT-rich parasite genes in Escherichia coli. Int J Parasitol 2000, 30: I I3-8.

124. McNulty DE, Claffee BA, Huddleston MJ, Porter ML, Cavnar KM, Kane JF: Mistranslational errors associated with the rare arginine codon CGG in Escherichia coli. Protein Expr Purif 2003, 27:365-74.

125. Dieci G, Bottarelli L, Ballabeni A, Ottonello S: tRNA-assisted overproduction of eukaryotic ribosomal proteins. Protein Expr Purif 2000, 18:346-54.

126. Mueller-Cajar O, Whitney S: Evolving improved Synechococcus Rubisco functional expression in Escherichia coli. Biochem 2008, 4 | 4:205-I4.

127. Ehmer PB, Jose J, Hartmann RW: Development of a simple and rapid assay for the evaluation of inhibitors of human 17 alphahydroxylase-C $(17,20)$-lyase $(\mathrm{P} 450 \mathrm{cl} 7)$ by coexpression of P450cl7 with NADPH-cytochrome-P450-reductase in Escherichia coli. J Steroid Biochem Mol Biol 2000, 75:57-63. 
128. Li C, Schwabe JW, Banayo E, Evans RM: Coexpression of nuclear receptor partners increases their solubility and biological activities. Proc Natl Acad Sci USA 1997, 94:2278-83

129. Vasseur-Godbillon C, Hamdane D, Marden MC, Baudin-Creuza V: High-yield expression in Escherichia coli of soluble human alpha-hemoglobin complexed with its molecular chaperone. Protein Eng Des Sel 2006, 19:91-7.

130. den Blaauwen T, Driessen AJ: Sec-dependent preprotein translocation in bacteria. Arch Microbiol 1996, 165:1-8.

131. Liu G, Topping TB, Randall LL: Physiological role during export for the retardation of folding by the leader peptide of maltose-binding protein. Proc Natl Acad Sci USA 1989, 86:92 I 3-7.

132. Hartl FU, Lecker S, Schiebel E, Hendrick JP, Wickner W: The binding cascade of SecB to SecA to SecY/E mediates preprotein targeting to the $E$. coli plasma membrane. Cell 1990, 63:269-79.

133. Danese PN, Silhavy TJ: Targeting and assembly of periplasmic and outer-membrane proteins in Escherichia coli. Annu Rev Genet 1998, 32:59-94.

134. Hanein D, Matlack KE, Jungnickel B, Plath K, Kalies KU, Miller KR, Rapoport TA, Akey CW: Oligomeric rings of the Sec6 Ip complex induced by ligands required for protein translocation. Cell 1996, 87:72I-32.

135. Nishiyama K, Suzuki T, Tokuda H: Inversion of the membrane topology of SecG coupled with SecA-dependent preprotein translocation. Cell 1996, 85:7|-8I.

136. Oates J, Barrett CM, Barnett JP, Byrne KG, Bolhuis A, Robinson C: The Escherichia coli twin-arginine translocation apparatus incorporates a distinct form of TatABC complex, spectrum of modular TatA complexes and minor TatAB complex. J Mol Biol 2005, 346:295-305.

137. de Lisa MP, Tullman D, Georgiou G: Folding quality control in the export of proteins by the bacterial twin-arginine translocation pathway. Proc Natl Acad Sci USA 2003, I00:6 I I 5-20.

138. Koch HG, Hengelage T, Neumann-Haefelin C, MacFarlane J, Hoffschulte HK, Schimz KL, Mechler B, Muller M: In vitro studies with purified components reveal signal recognition particle (SRP) and SecA/SecB as constituents of two independent proteintargeting pathways of Escherichia coli. Mol Biol Cell 1999, 10:2163-73.

139. Serek J, Bauer-Manz G, Struhalla G, Berg L van den, Kiefer D, Dalbey $R$, Kuhn A: Escherichia coli YidC is a membrane insertase for Sec-independent proteins. EMBO J 2004, 23:294-30I.

140. Chou CP, Tseng JH, Kuo BY, Lai KM, Lin MI, Lin HK: Effect of SecB chaperone on production of periplasmic penicillin acylase in Escherichia coli. Biotechnol Prog 1999, 15:439-45.

14l. Ignatova Z, Mahsunah A, Georgieva M, Kasche V: Improvement of posttranslational bottlenecks in the production of penicillin amidase in recombinant Escherichia coli strains. Appl Environ Microbiol 2003, 69: 1237-45.

142. Barrett CM, Ray N, Thomas JD, Robinson C, Bolhuis A: Quantitative export of a reporter protein, GFP, by the twin-arginine translocation pathway in Escherichia coli. Biochem Biophys Res Commun 2003, 304:279-84.

143. de Lisa MP, Lee P, Palmer T, Georgiou G: Phage shock protein PspA of Escherichia coli relieves saturation of protein export via the Tat pathway. J Bacteriol 2004, 186:366-73.

144. Graubner W, Schierhorn A, Bruser T: DnaK plays a pivotal role in Tat targeting of CueO and functions beside SlyD as a general Tat signal binding chaperone. J Biol Chem 2007, 282:7116-24.

145. Pérez-Rodríguez R, Fisher AC, Perlmutter JD, Hicks MG, Chanal A, Santini CL, Wu LF, Palmer T, DeLisa MP: An essential role for the DnaK molecular chaperone in stabilizing over-expressed substrate proteins of the bacterial twin-arginine translocation pathway. J Mol Biol 2007, 367:7 I5-30.

146. Hayhurst A, Harris W]: Escherichia coli Skp chaperone coexpression improves solubility and phage display of single-chain antibody fragments. Protein Expr Purif 1999, 15:336-43.

147. Mavrangelos C, Thiel M, Adamson PJ, Millard DJ, Nobbs S, Zola H, Nicholson IC: Increased yield and activity of soluble singlechain antibody fragments by combining high-level expression and the Skp periplasmic chaperonin. Protein Expr Purif 200I, 23:289-95.
148. Bothmann H, Plückthun A: Selection for a periplasmic factor improving phage display and functional periplasmic expression. Nat Biotechnol 1998, 16:376-80.

149. Lin B, Renshaw MW, Autote K, Smith LM, Calveley P, Bowdish KS, Frederickson S: A step-wise approach significantly enhances protein yield of a rationally-designed agonist antibody fragment in E. coli. Protein Expr Purif 2008, 59:55-63.

150. Maynard J, Adams EJ, Krogsgaard M, Petersson K, Liu CW, Garcia KC: High-level bacterial secretion of single-chain alphabeta $T$ cell receptors. J Immunol Methods 2005, 306:5 I-67.

15I. Narayanan N, Chou CP: Physiological improvement to enhance Escherichia coli cell-surface display via reducing extracytoplasmic stress. Biotechnol Prog 2008, 24:293-30I.

152. Skorko-Glonek J, Sobiecka-Szkatula A, Narkiewicz J, Lipinska B: The proteolytic activity of the HtrA (DegP) protein from Escherichia coli at low temperatures. Microbiology 2008, 154:3649-58.

153. Lin Y-H, Fang W-L, Lin WJ, Huang S-W, Chou CP: Improving production of penicillin acylase in Escherichia coli via efficient DegP-mediated processing of precursors in periplasm. Process Biochem 200I, 37:23-30.

154. Pan KL, Hsiao HC, Weng CL, Wu MS, Chou CP: Roles of DegP in prevention of protein misfolding in the periplasm upon overexpression of penicillin acylase in Escherichia coli. J Bacteriol 2003, 185:3020-30.

155. Nakamoto H, Bardwell JC: Catalysis of disulfide bond formation and isomerization in the Escherichia coli periplasm. Biochim Biophys Acta 2004, 1694: I II-9.

156. Missiakas D, Georgopoulos C, Raina S: The Escherichia coli dsbC (xprA) gene encodes a periplasmic protein involved in disulfide bond formation. EMBO J 1994, 13:2013-20.

157. Rietsch A, Belin D, Martin N, Beckwith J: An in vivo pathway for disulfide bond isomerization in Escherichia coli. Proc Natl Acad Sci USA 1996, 93: 13048-53.

158. Wülfing C, Rappuoli R: Efficient production of heat-labile enterotoxin mutant proteins by overexpression of $d s b A$ in a $\operatorname{deg} P$ deficient Escherichia coli strain. Arch Microbiol 1997, 167:280-3.

159. Jeong KJ, Lee SY: Secretory production of human leptin in Escherichia coli. Biotechnol Bioeng 2000, 67:398-407.

160. Qiu J, Swartz JR, Georgiou G: Expression of active human tissuetype plasminogen activator in Escherichia coli. Appl Environ Microbiol 1998, 64:489|-6.

16I. Bessette PH, Aslund F, Beckwith J, Georgiou G: Efficient folding of proteins with multiple disulfide bonds in the Escherichia coli cytoplasm. Proc Natl Acad Sci USA 1999, 96:13703-8.

162. Maskos K, Huber-Wunderlich M, Glockshuber R: DsbA and DsbCcatalyzed oxidative folding of proteins with complex disulfide bridge patterns in vitro and in vivo. J Mol Biol 2003 , 325:495-5I3.

163. Joly JC, Leung WS, Swartz JR: Overexpression of Escherichia coli oxidoreductases increases recombinant insulin-like growth factor-I accumulation. Proc Natl Acad Sci USA 1998, 95:2773-7.

164. Zhang Y, Olsen DR, Nguyen KB, Olson PS, Rhodes ET, Mascarenhas $D$ : Expression of eukaryotic proteins in soluble form in Escherichia coli. Protein Expr Purif 1998, I 2:159-65.

165. Kurokawa Y, Yanagi H, Yura T: Overproduction of bacterial protein disulfide isomerase (DsbC) and its modulator (DsbD) markedly enhances periplasmic production of human nerve growth factor in Escherichia coli. J Biol Chem 200I, 276:14393-9.

166. Kurokawa $Y$, Yanagi $H$, Yura $T$ : Overexpression of protein disulfide isomerase DsbC stabilizes multiple-disulfidebonded recombinant protein produced and transported to the periplasm in Escherichia coli. Appl Environ Microbiol 2000, 66:3960-5.

167. Hoshino K, Eda A, Kurokawa Y, Shimizu N: Production of brainderived neurotrophic factor in Escherichia coli by coexpression of Dsb proteins. Biosci Biotechnol Biochem 2002, 66:344-50.

168. Yuan S, Duan H, Liu C, Liu X, Liu T, Tao H, Zhang Z: The role of thioredoxin and disulfide isomerase in the expression of the snake venom thrombin-like enzyme calobin in Escherichia coli BL2I (DE3). Protein Expr Purif 2004, 38:5I-60.

169. Garcia-Ortega L, Lacadena J, Lacadena V, Masip M, De Antonio C, Martinez-Ruiz A, Martinez Del Pozo A: The solubility of the ribotoxin alpha-sarcin, produced as a recombinant protein in Escherichia coli, is increased in the presence of thioredoxin. Lett Appl Microbiol 2000, 30:298-302. 
170. Zhang ST, Shi J, Zhao J, Qi YF, Guo AG: Expression of soluble and functional snake venom fibrinolytic enzyme fibrolase via the co-expression of DsbC in Escherichia coli. Protein Pept Lett 2006, I 3:559-63.

171. Gothel SF, Marahiel MA: Peptidyl-prolyl cis-trans isomerases, a superfamily of ubiquitous folding catalysts. Cell Mol Life Sci 1999, 55:423-36.

172. Kleerebezem M, Heutink M, Tommassen J: Characterization of an Escherichia coli rotA mutant, affected in periplasmic peptidylprolyl cis/trans isomerase. Mol Microbiol 1995, 18:3 I3-20.

173. Bothmann H, Plückthun A: The periplasmic Escherichia coli peptidylprolyl cis, trans-isomerase FkpA. Increased functional expression of antibody fragments with and without cis-prolines. J Biol Chem 2000, 275:17100-5.

174. Wülfing C, Plückthun A: Correctly folded T-cell receptor fragments in the periplasm of Escherichia coli. Influence of folding catalysts. J Mol Biol 1994, 242:655-69.

175. Antonoaea R, Furst M, Nishiyama K, Muller M: The periplasmic chaperone PpiD interacts with secretory proteins exiting from the SecYEG translocon. Biochemistry 2008, 47:5649-56.

176. Missiakas D, Betton JM, Raina S: New components of protein folding in extracytoplasmic compartments of Escherichia coli SurA, FkpA and Skp/OmpH. Mol Microbiol 1996, 21 :87I-84

177. Zhang Z, Song LP, Fang M, Wang F, He D, Zhao R, Liu J, Zhou ZY, Yin $C C$, Lin $Q$, Huang $H L$ : Production of soluble and functional engineered antibodies in Escherichia coli improved by FkpA. Biotechniques 2003, 35: 1032-8.

178. Padiolleau-Lefevre S, Debat H, Phichith D, Thomas D, Friboulet A, Avalle B: Expression of a functional scFv fragment of an antiidiotypic antibody with a beta-lactam hydrolytic activity. Immunol Lett 2006, 103:39-44.

179. Wu MS, Pan KL, Chou CP: Effect of heat-shock proteins for relieving physiological stress and enhancing the production of penicillin acylase in Escherichia coli. Biotechnol Bioeng 2007, 96:956-66.

180. Park JS, Han KY, Lee JH, Song JA, Ahn KY, Seo HS, Sim SJ, Kim SW, Lee J: Solubility enhancement of aggregation-prone heterologous proteins by fusion expression using stress-responsive Escherichia coli protein, RpoS. BMC Biotechnol 2008, 8:15.

18I. Han KY, Song JA, Ahn KY, Park JS, Seo HS, Lee J: Solubilization of aggregation-prone heterologous proteins by covalent fusion of stress-responsive Escherichia coli protein, SlyD. Protein Eng Des Sel 2007, 20:543-9.

182. Han KY, Seo HS, Song JA, Ahn KY, Park JS, Lee J: Transport proteins PotD and Crr of Escherichia coli, novel fusion partners for heterologous protein expression. Biochim Biophys Acta 2007, 1774:1536-43.

183. Esposito D, Chatterjee DK: Enhancement of soluble protein expression through the use of fusion tags. Curr Opin Biotechnol 2006, I7:353-8.

184. Peti W, Page R: Strategies to maximize heterologous protein expression in Escherichia coli with minimal cost. Protein Expr Purif 2007, $51: 1-10$.

185. Ostermeier M, De Sutter K, Georgiou G: Eukaryotic protein disulfide isomerase complements Escherichia coli dsbA mutants and increases the yield of a heterologous secreted protein with disulfide bonds. J Biol Chem 1996, 27I:10616-22.

186. Zhan X, Schwaller M, Gilbert HF, Georgiou G: Facilitating the formation of disulfide bonds in the Escherichia coli periplasm via coexpression of yeast protein disulfide isomerase. Biotechnol Prog 1999, 15:1033-8.

187. Ferrer M, Chernikova TN, Timmis KN, Golyshin PN: Expression of a temperature-sensitive esterase in a novel chaperone-based Escherichia coli strain. Appl Environ Microbiol 2004, 70:4499-504.

188. Robin S, Togashi DM, Ryder AG, Wall JG: Trigger factor from the psychrophilic bacterium $P$. frigidicola is a monomeric chaperone. J Bacteriol 2009, 191: I |62-1 I68.

\section{Publish with Bio Med Central and every} scientist can read your work free of charge

"BioMed Central will be the most significant development for disseminating the results of biomedical research in our lifetime. "

Sir Paul Nurse, Cancer Research UK

Your research papers will be:

- available free of charge to the entire biomedical community

- peer reviewed and published immediately upon acceptance

- cited in PubMed and archived on PubMed Central

- yours - you keep the copyright
BioMedcentral 